Uncommon Layouts in the Plans of Ottoman Mosques in Greece (Rohodes and Crete Islands)

\title{
Uncommon Layouts in the Plans of Ottoman Mosques in Greece (Rohodes and Crete Islands)
}

\author{
Abdelwahab Mohamed \\ Associate Prof. Islamic Architecture, Faculty of Archaeology- Fayoum University \\ maa02@fayoum.edu.eg
}

\begin{abstract}
The subject of this research is based on a survey of Ottoman mosques by the author in Greece, where around seven types were used in the Mosque design; three of them were very common and were separated across Greece (the single-unit- the T-plan- the "Eywan" Mosque- the quatrefoil plan), while three layouts were considered uncommon types of Ottoman mosques in Greece (the courtyard- the octagonal- the multi-domed mosques). In addition, uncommon elements were used in some mosques, such as the pogada roof of Ali Paşa Hilmi in Rhodes Island. The research aims to study the unconventional plan layout typology of Ottoman mosques and identify the extent to which these layouts were connected with the known Ottoman architecture. By offering the common Ottoman styles in Greece in general, the author selects some examples of Mosques and analyzes their morphologies. As a result, the architectural typologies of the floor plan of historical mosques in Greece were identified. The study concluded several types of plans. The current paper revealed that the typology of plans in historical mosques in Greece related to the plan typology of Islamic known styles.
\end{abstract}

Keywords: Ottoman Mosques- Typology- Rhodes- Crete- Mosque typology

\section{1-Introduction}

Typology is the categorized study of the physical characteristics of the built circumstances and environment into various styles. It is not a model that has to be constructed according to the exact shape, it is more ambiguous, independent but identifiable. Therefore, the term "typology" refers to the classification of common things (Mustafa, 2019).

It may be useful here to define the meaning of architectural style and when to apply the term style to a design. The meaning of type doesn't mean the copy of the layout, but it is a process of getting the quality of systematic arrangements (Gulgonen,1982). Typology is the categorized study of the physical characteristics of the built environment into various types. Typological thought refers to the whole, 
the manifold relationships among things, the extreme, and, at the same time, the harmonious.

To understand the built spaces, there are many methods, such as typology, which is one of the most important ways to provide better understanding of the arrangements of space and form of the mosque architecture. It is taken deeper as a process of getting the quality of formal arrangements. Thus, it could be said that the "type" is not a model, which has to be built according to the exact look; it is more independent and ambiguous, but identifiable (Mustafa, 2019).

There are many ways to explore and provide better understanding of the built space, and classification is one of the most powerful tools in this field. The types and classifications are important topics in Islamic architecture. It can be considered as important as the other major concepts of space, architecture, and form.

There are still many Ottoman mosques that date back to the first half of the fifteenth Gregorian century in Greece and the Balkans, which were built according to common architectural styles throughout the Ottoman Empire in Europe, Asia, and Africa. They were designed according to literary studies that focused on Ottoman architecture into architectural styles, such as the Bursa I, II, III, as well as the classic or imperial styles (Freely, 2011). As these classifications depended on the general characteristics of the designs, the general shape of the mosque, and space, other rules were the basis for the classification, including the coverings, such as the dome mosque (Mustafa, 2019).

The studies of the typologies and pattern layouts of mosques differ in place and time. This is clear in a wide range of relevant studies. Many investigations and studies were carried out to classify the common types of mosques in Greece and Balkan in general, depending on the layout characters of the Ottoman mosques in this area.

At the level of form, Ballducci (Balducci, 1932) studied the common architectural types of the mosques, türbes, fountains, and houses in Rhodes Island without carrying analysis or comparison studies. However, this study was the textbook of all studies on the Ottoman heritage in Rhodes. 


\section{Uncommon Layouts in the Plans of Ottoman Mosques in Greece (Rohodes and Crete Islands)}

Studies conducted by Keil (Kiel, 1990) explored the typology and distribution of the Ottoman mosques. His studies investigated the characteristics of the mosque types and the plans of the prayer hall by analyzing and classifying the mosque according to its layouts. Brouskari (Brouskari, 2008) examined all mosques across Greece. This study enabled the scholars to have a complete overview of the Ottoman mosques in this area.

Abdelwahab (Abdel wahab, 2010) carried out a typological study on the Ottoman mosques in the old town of Rhodes based on the ground plan of the building to classify the mosques to comprehend the framework of design identity. The study focused on the typology of Rodian mosques inside the old town of Rhodes. He investigated and analyzed the methodology of 8 mosques that were constructed between the $16^{\text {th }}-19^{\text {th }}$ centuries. According to the study of Loukma (Loukm , 2017) et al., the typology of Ottoman mosques in Greece was separated into two main categories: Single-unit mosques and multi-space mosques.

Moreover, Ameen (Ameen, 2017) studied the typology of Ottoman mosques in Greece. He surveyed and analyzed the designs of the remaining mosques focusing and comparing the traditional types of mosque designs in Balkan and Minor Asia. The inclusion of uncommon mosque styles within the list of mosque styles without focusing on their architectural origins and the reasons that led to the use of these designs. This is the point that the current study will adopt.

In a different context, İbrahimgil and İbrahimgil (İbrahimgil , 2018) surveyed the different types of Ottoman architecture in Rhodes Island focusing on the main building materials, inscriptions, and architectural elements. As a result, they identified Ottoman architecture in relation to its functions.

The literature shows that a few studies try to address the topic of uncommon designs of Ottoman mosques in Greek lands, despite the heritage richness of these irregular and unique types.

\section{2-Research problem}

The Greek lands contain many historical mosques that were built in different areas with well-known designs. Although there were some studies on the mosques of Greece and Balkan from different points of view, no adequate attention has been paid to the plan typology of uncommon designs and elements. The paper raises the 
following questions to facilitate the research process and help find compelling answers to the research problem:

- What is the typology of uncommon plans in Ottoman mosques in the Greek islands and their existing example?

- What are the origins of these uncommon designs? Why had the architect used them?

\section{3-Research objectives}

The paper seeks to achieve the following objectives:

- Define the inventory layout of the non-traditional or uncommon models of mosques in the Greek islands.

- Determine the various reasons that prompted the architect to design mosques according to this uncommon style.

\section{4-Research methodology}

To get the ideal answers to the research questions and solve the problem of the study to achieve the study objectives, the study adopted these methodological steps:

- A review of known and common Ottoman types of mosque architecture, in particular, and the ground plan and space typology.

- Having a research sample of 6 mosques built by Ottomans in Greek islands and analyzing the ground plans and their characteristic elements.

- Comparing the layout and plan typology of the selected mosques and uncommon elements with the known Ottoman typologies in Greece and Balkan.

\section{5-Discussion}

The Ottoman rule in the Balkan started from the $14^{\text {th }}$ until the early $20^{\text {th }}$ century. The province of the Ottoman Empire was the Greek lands of Macedonia and the islands. In this era, some cities were developed and reformed, such as Thessaloniki, Rhodes Heraklio, Rythmno, Ierapetra, and Xania. Despite the variety of the cultural nature of this island and its cities, everyone had its special features (Ameen, 2019).

As usual, the Ottomans in all the occupied territories followed the same policy to satisfy the religious, social, and aesthetical needs of people by establishing a chain 


\section{Uncommon Layouts in the Plans of Ottoman Mosques in Greece}

(Rohodes and Crete Islands)

of various buildings. Many studies estimated the total number of the Ottoman edifices in Greece by 3771, including 2336 Mosques and mescids (Nusret, 2000).

The Greek lands have huge numbers of cultural heritage dated back to the first half of the $16^{\text {th }}$ century, including many archaeological mosques. Although some researchers studied these mosques of the islands from different points of view, there is still a lack of analytical studies on the uncommon layouts and typology of these mosques.

The present study highlights the uncommon ground plan typology of Ottoman mosques, tracing them with the common plan typologies in the Greek mainland as an attempt to fill this gap of information on such topics.

The main question here is "what were the factors that prompted the architect to design these unusual plans in Ottoman architecture?". Perhaps, the answer is that these plans were a direct result of the influence of the site or the available space. Moreover, the usual Ottoman tradition of using the old ruined sites with their foundations and floors was a basis for these new constructions, which forced the architect to modify his architectural plans according to these old foundations. This resulted in layouts that formed architectural styles, not widespread and unconventional in the mosque architecture.

As noted from the literature, a few studies tried to address the uncommon layouts of Ottoman mosques in the Greek mainland, especially the ones that analyzed the traditional types of mosques, such as the three types of Bursa and the classical one. Therefore, this paper is an attempt to handle the topic of uncommon plans, particularly the existing mosques in Rhodes and Crete islands.

The aim of the research is to study the unconventional plan layout typology of Ottoman mosques and identify to which extent these layouts were connected with the known Ottoman architecture. By offering the common Ottoman styles in Greece, in general, the author selected some examples of mosques and analyzed their morphologies.

In Greece mainland, many mosques were not designed according to the architectural styles known in Ottoman architecture. Therefore, each of them adopted a unique design that might be unprecedented in the designs of Ottoman mosques, whether from the layout of the city or the coverage, such as the Mosque of Hamza Bey (Alkazar) in Thessaloniki (872-873AH/1467-1468AD) (Kaplan, 2016), the 
Şadırvan Camii (1305AH/ 1888AD), and Ali Hilmi Paşa Mosque (1327AH/ 1909AD) in Rhodes. The other examples are the Mosque of Valda Trukhan Khadija (1050-1058AH/1640-1648AD) and the Mosque of Ghazi Della Hussein (10561067AH/1646-1656AD) (Brouskari, 2008) in Rethymno and Yali Tzami in Xania (1056-1058AH/1646-1648AD) (Andrianankis, 1997).

We can recognize all the features of the styles of Islamic architecture in Greece from the $16^{\text {th }}$ to $19^{\text {th }}$ centuries, define the connections between this style and the original style in Turkey itself, and decide whether it was a pure imitation or it had an independent character, as we had seen in other Ottoman provinces, especially the Ottoman Arab and European Countries, or if it gathered both of them. Also, we could decide the features of creation which we do not find in the Ottoman architecture in Turkey itself and Anatoly or the Arab Ottoman provinces (Hamza, 2002).

Archaeological studies on the Balkans, in general, and Greece, in particular, proved that the architecture of the Ottoman mosques followed the same architectural styles known throughout the Ottoman Empire, especially the European side and Anatolia. This was probably a result of similar environmental factors in these regions (Kiel, 1983).

The architectural styles of the mosques in Greece should be identified and their general features should be defined. Thus, the unusual architectural designs designed according to special circumstances can be revealed. We will try to define them in this study.

Studying the typology of mosques in Greek islands is a complicated idea due to the different considerations, which affected the forms, geographical and multifunctions, location, and the architects, etc., which lead to different classifications. Many pieces of research handled the classification of the Ottoman mosques both chronologically and geographically, such as the Seljuk architecture in Anatolia as a traditional type of Ottoman mosques, the Bursa styles, then the Edrine, and finally 


\section{Uncommon Layouts in the Plans of Ottoman Mosques in Greece (Rohodes and Crete Islands)}

Stanbule (Aslanapa.1987). Other studies considered the origin, inspiration, function, or the architect, etc. as the base of typology (Balducci , 1932). Here, the study will examine the plan and classify the mosques according to the available examples (Ameen, 2017).

\section{6-The common typology of Ottoman mosques;}

The mosques in the Greek mainland are characterized by simplicity and geometry based on the tradition of each area. According to the typological characteristics, they are classified into three main general categories (Fig. 1):
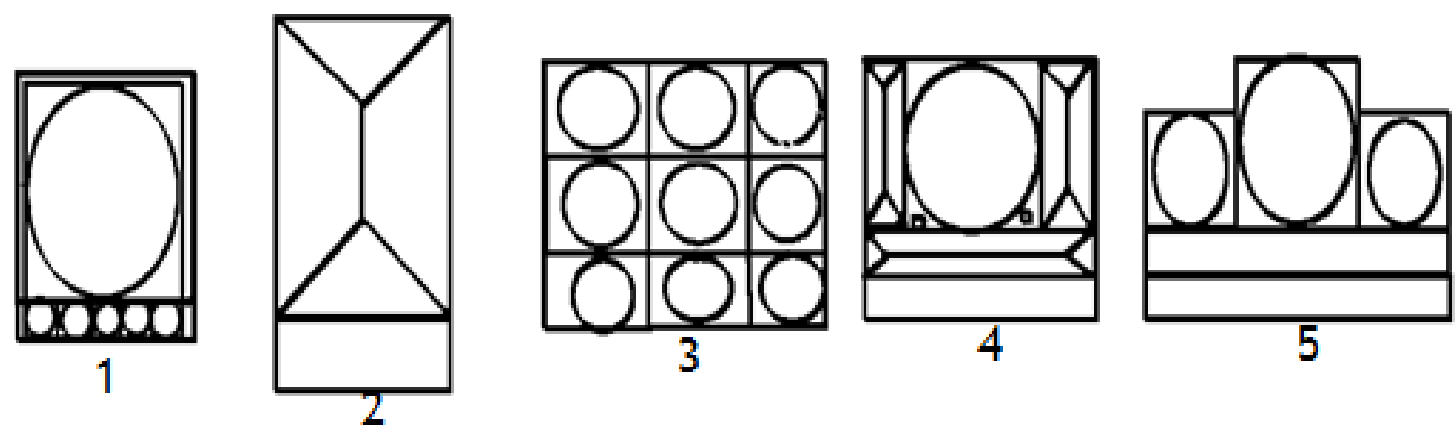

(Fig. 1): The common types of Ottoman mosques in Greece

\subsection{The single- unite Mosque:}

The Ottoman mosques in Greece, in general, began very modestly with a series of buildings comprising a simple domed cube with a lateral vestibule, such as the Mosque Eski Cami of Komotini from the $14^{\text {th }}$ century in Rhodes; the Mosque of Ibrahim Paşa (947-948AH/ 1540-1541AD) (Brouskari, 2008) (fig.2 ), Rejeb Paşa (996-997AH/ 1587-1588AD) (Fig.3), Murad Reis Mosque and the Mosque of Hamza Bey (1305AH/ 1887AD) (Balducci, 1932) and Yeni Saray Aga in Xania in Crete island from the $17^{\text {th }}$ century; Sultan Ibrahim, Kara Musa Paşa, in Rythmno in Crete, the Mosque of Mustafa Vofvoda in Athens (1177AH/ 1763AD) (Ayverdi , 1966) This category was used in Anatolia before the Ottomans by the Seljuks in 
Konya, such as Beshare Bey Mosque (610AH/ 1213AD) and Erdemshah Mosque (617AH/ 1220AD) (Aslanapa, 1987).

The oldest existing single-domed mosque in Greece stands in Komotini is Evrenos Bey Mosque (777-787AH/ 1375-1385AD)( Kiel, 1981). Later, the single-unit mosques were enlarged by lateral spaces and side units in many existing mosques, such as Mustafa Bey Mosque in Serres. It could be said that, chronologically and geographically, the domed space type is the main architectural form in Turkish Greece (Ameen ,2017)

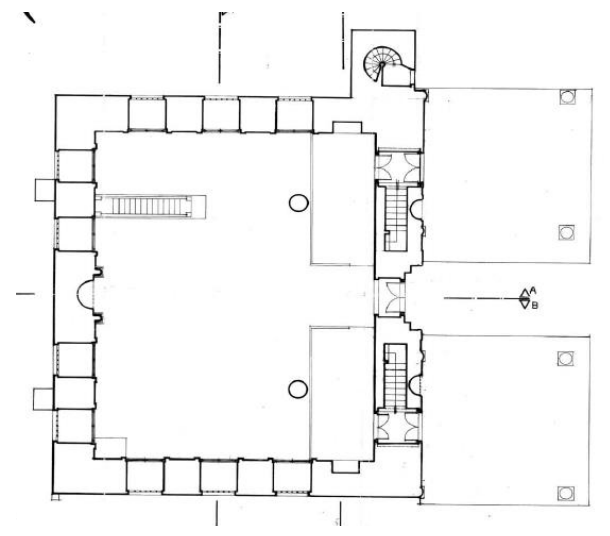

(Fig..2): plan of Ibrahim Paşa mosques in Rhodes (Abdelwahab. 2010)

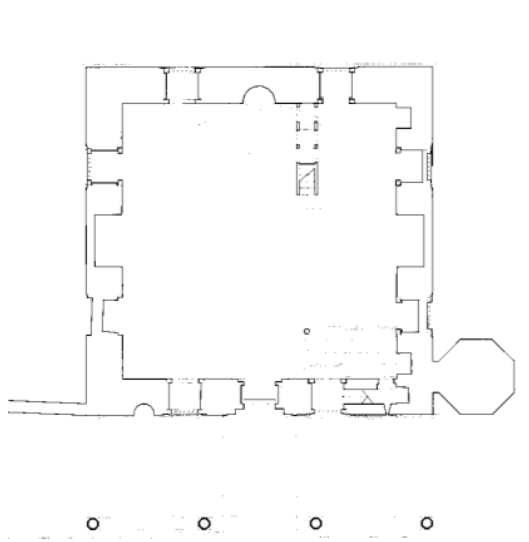

(Fig..3): plan of Rejeb Paşa Mosque in Rhodes. (Archive of the ofifice of the conservation of the medieval town)

\subsection{The single-unit mosques with lateral spaces;}

Studies differed concerning the names of this type of mosque. Some studies classified this category as the second mosque layout in early Ottoman architecture and called it earring layout or pendentive design. Its name was borrowed from the pendent form and shape of the plan. It was derived from the aerialist single dome layout by adding smaller spaces on both sides of the main prayer area (Mustafa, 2019). Also, it is known as zawia-mosque or convent mosque depending on its function (Panagiotis, 2012). However, according to the layout of the constructions, it is classified as a reverse-T plan (Kuran, 1968). The Ottoman architecture has kept many existing constructions in Turkey, such as Hatuniya Mosque in Trabzon (920AH/ 1514AD) (Fig.4) (Slie, 1993). In Greek lands, the oldest examples are the 
Imaret of Ghazi Evrenos Bey (777-787AH/ 1375- 1385AD) (Fig.5), Mehmet Bey Mosque (898AH/ 1492AD) in Serres (Fig.6) (Ameen, 2017), the Imaert of Beyazit in Edrin (805AH/ 1402AD) (Panagiotis, 2012), and Zaviye of Ishak Bey, Skopje (842AH/ 1438-9 AD). The last example is the Suleyman Mosque (930AH/ 1523 AD) in Rhodes Island (Abdelwahab, 2010).

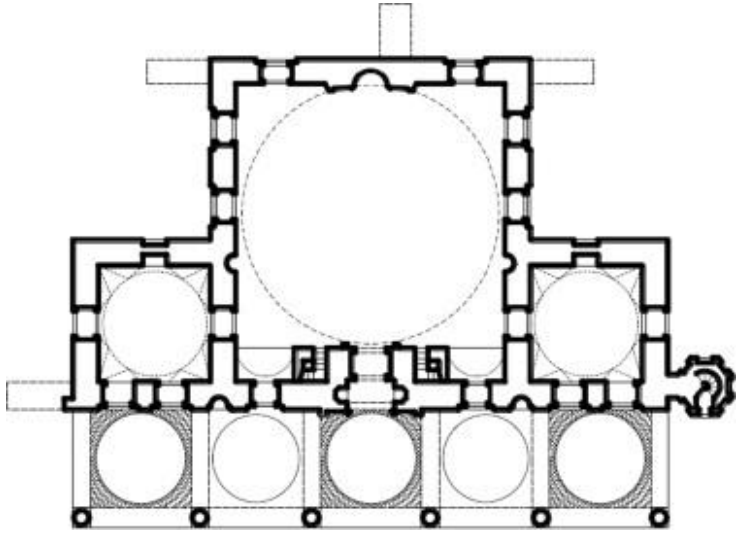

(Fig. 4) The T-plan layout of Hatuniya Mosque in Trabzon (920AH/ 1514AD) (Mustafa, 2019)

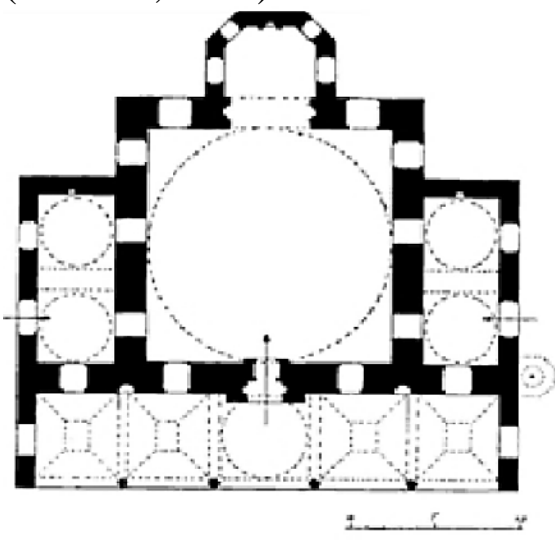

(Fig. 6) The T-plan layout of Mehmet Bey Mosque (898AH/ 1492AD) in Serres (Kiel. 1983)

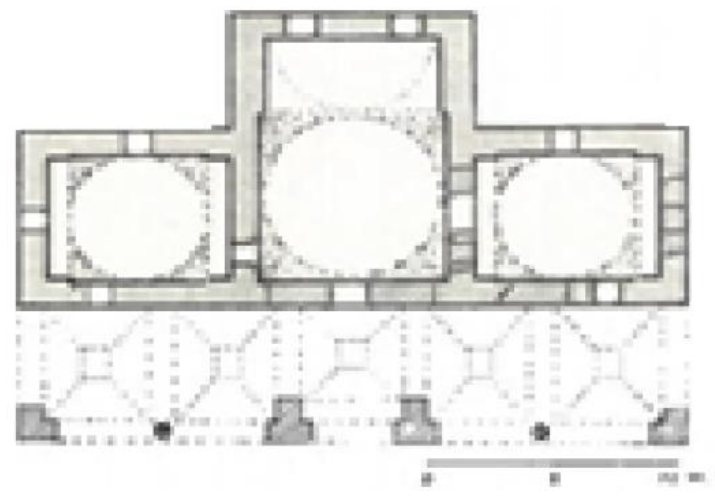

(Fig. 5) The T-plan layout of Imaret of Ghazi Evrenos Bey (777AH-787AH/ 13751385AD).

(Kiel,

1981)

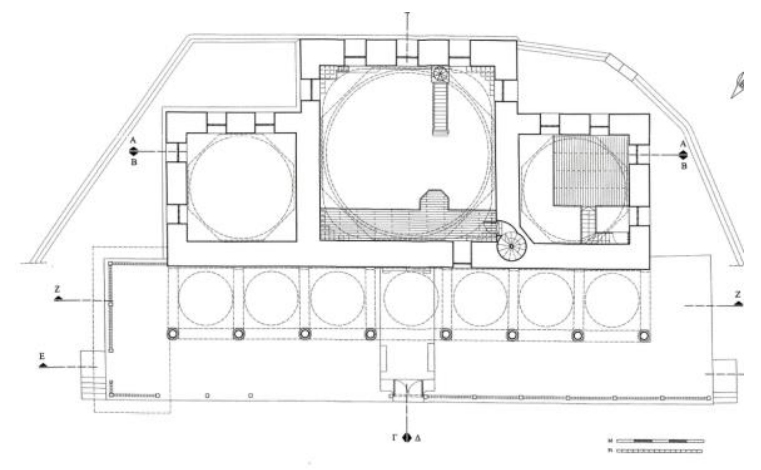

(Fig. 7) The T-plan layou of Sultan Suleiman Mosque in Rhodes. (Archive of the ofifice of the conservation of the medieval town)

\section{The uncommon layouts:}

As mentioned, during the present survey in Greek lands, six buildings designed with uncommon layout were found in the cities of Thessaloniki, Rhodes, and Crete islands. The examples that the study covered were the uncommon 
(untraditional) ground plan of archaeological mosques, whereas the plan will be analyzed graphically according to their morphology and layout by comparing with the known examples of Ottoman mosques to identify the plan typology used.

\subsection{Duplication dome layout or the multi-domed Mosque:}

This category is a duplication dome layout design, which was developed from the multiple dome. The form of the design in this type is rectangular, and the layout is divided into units by columns, pillars, or walls. In many cases, the porch can be observed. The spans are yielded by columns and pillars supporting the arcade of arches (Mustafa, 2019). The standard example of this type is the Ulu Cami, Bursa (799-802AH/ 1396-1399AD) (Ayverdi, 1989) (Fig.8- Pl. 1). In Greece, there is no complete example of this planning, whereas the ground plan was adapted is Vali Paşa Mosque in Rethymno, Crete (1062AH/ 1651AD) that represented the characteristics of this type with just two arcades with six domes and three in the front portico (Fig.9. Pl. 2 ). The same layout was used in Ali Paşa Mosque, Atik Ali Paşa in Zengrly (Fig. 10) (Hamza, 2002), as well as the Ottoman commercial buildings, such as the Bedesten of Serres (900AH/ 1494AD) (Eleni, 2004), but without the front portico (fig .11).

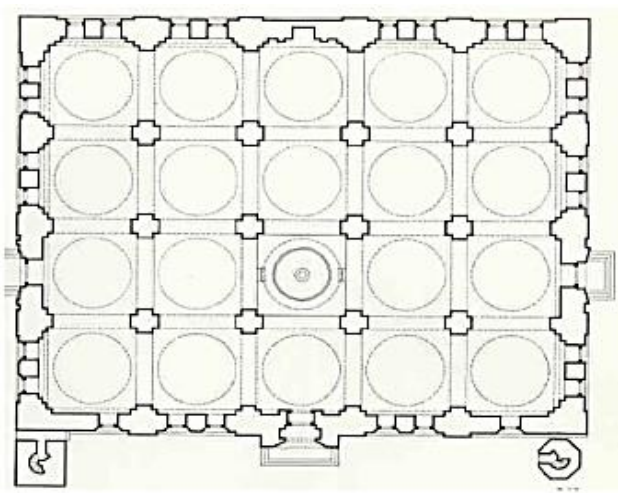

(Fig. 8). Plan of Ulu Cami, Bursa, (Hattstein, 2000), Islam Art and Architecture, Koneman. P. 544.

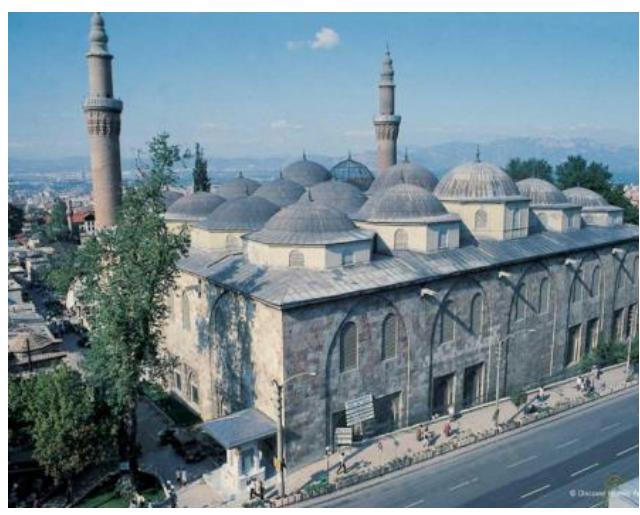

(Pl. 1) Duplication dome layout of Ulu Cami, Bursa.

(http://islamicart.museumwnf.org/da tabase_item.php?id=monument;ISL; tr;Mon01;16;en) 
Uncommon Layouts in the Plans of Ottoman Mosques in Greece (Rohodes and Crete Islands)

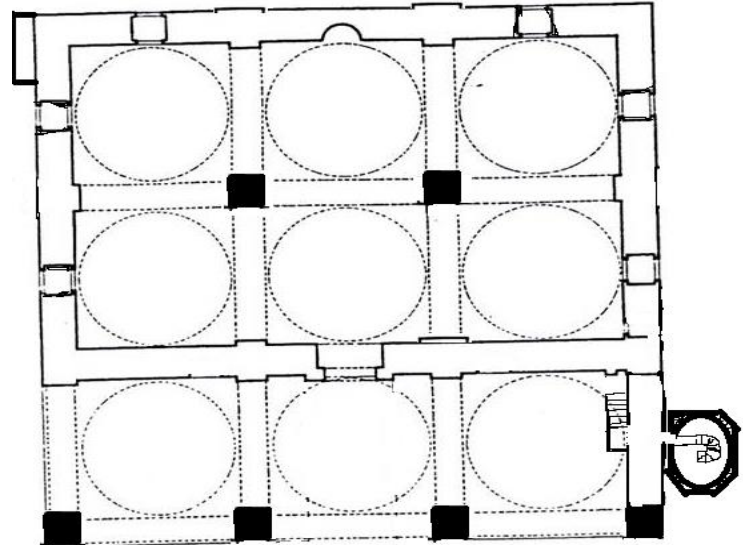

(Fig.9): Duplication dome layout of Vali Paşa Mosque in Reythemno in Crete 1651 (Bourskari, 2008)

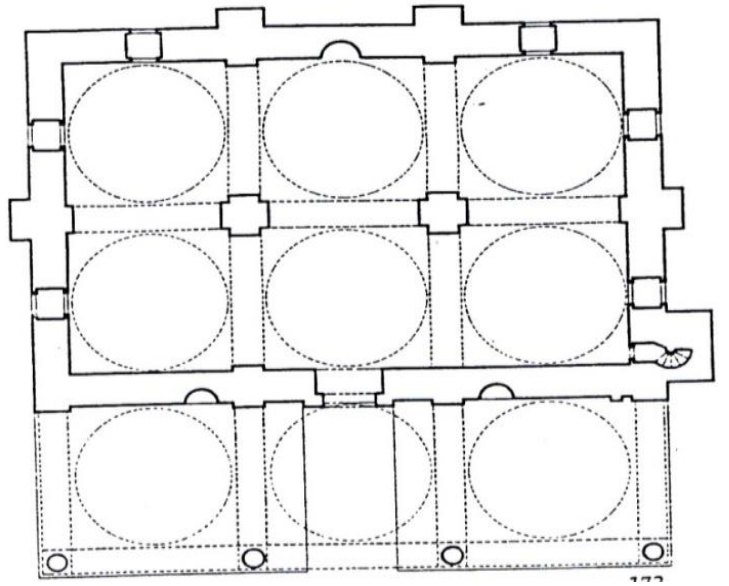

(Fig. 10) Plan of Ali Paşa Mosque, Zengrlli Kubu. (Hamza. 2002)

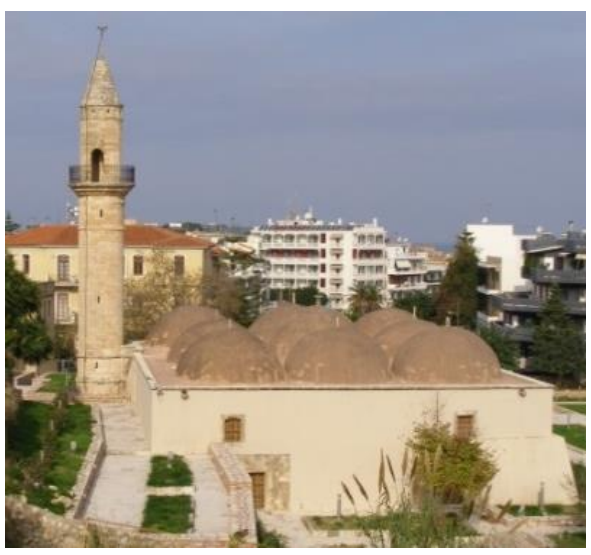

(P1.2): the Duplication dome layout of Vali Paşa Mosque in Reythemno in Crete 1651.

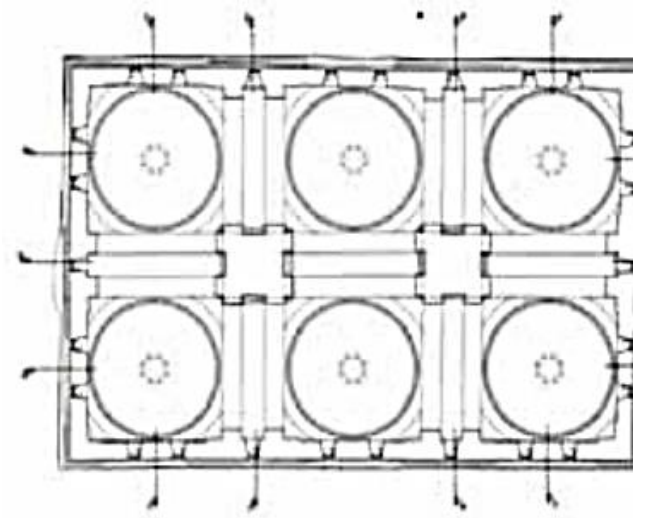

(Fig. 11). : plan of Bedestan of Serres (Kiel, 1983))

\subsection{Courtyard layout design}

The courtyard layout is a unique category of Ottoman mosques in Greece, while it is the traditional layout of the mosque in Arabian provinces. There is only one existing example in Greece, i.e., Hamza Bey Mosque (Alkazar) in Thessaloniki (872-873AH/ 1467/1468) (Fig.12- Pl.3). It didn't survive in its original form, but it was the result of many subsequent additions. It is the largest mosque in Greece with an area of $30 \mathrm{~m} \times 40 \mathrm{~m}$. The mosque has a somewhat unusual ending planned with a columned open courtyard, which is the only known example outside the old Ottoman capitals: Istanbul and Adrianople (Cincin, 2016).

The Mosque of Hamza Bey has a rather unusual plan with the courtyard with the fountain found in Ottoman architecture according to Kuran (Kuran,1968) in Ulu 
Camii and Isak Bey ( 768 AH/ 1366 AD) in Manisa and Selçuk İsa Bey Mosque (776AH/ 1373AD) (Ogan, 1956: Ameen, 2017) (Fig. 13- Pl.4). A good example of this category is the Guzelce Hassan Bey Mosque in Hayrabolu, Turkey (Fig. 14) which is not used much in Anatolian Turkish architecture except for a few examples. The principles of this new plan scheme, which had significant effects on Anatolian Turkish architecture starting from the period it belonged to, were based on Islamic architecture in Syria and had an ancient history back to the Damascus Umayyad Mosque. The architectural innovation brought by this application was the courtyard with portico, which was added to the mosque.

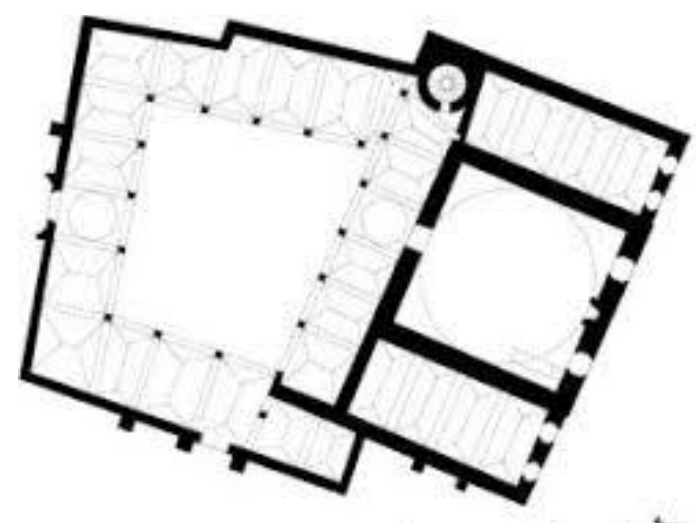

(Fig.12) The courtyard layout of Hamza Bey Mosque (Alkazar), Thessaloniki (Cincin, 2016).

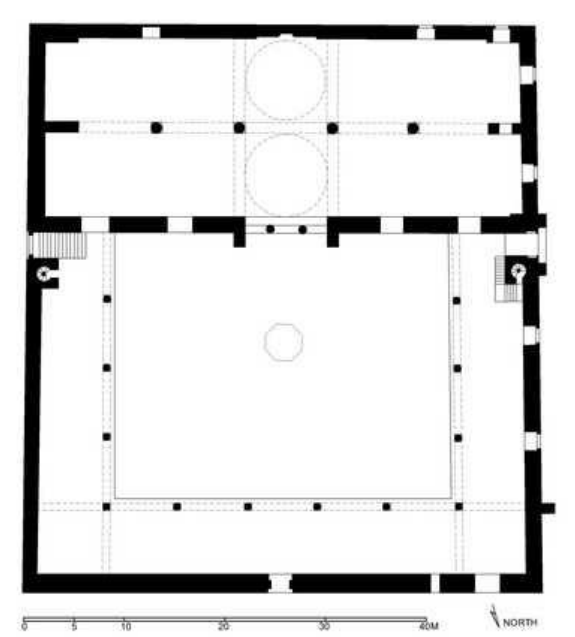

(Fig.13) The courtyard layout of Selçuk İsa Bey Cami.

https://okuryazarim.com/category/sanat -tarihi/beylikler-donemi-sanati/

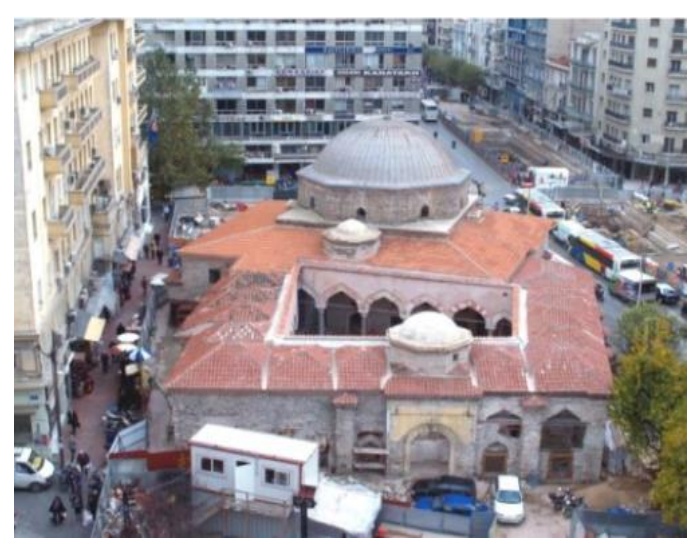

(Pl.3)The Mosque of Hamza Bey, Thessaloniki (Ameen, 2010)

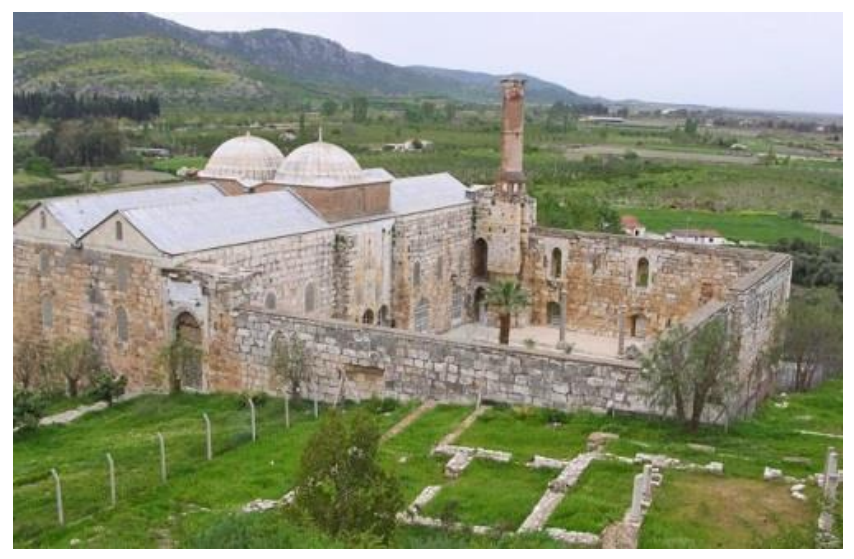

(Pl. 4) Selçuk İsa Bey Cami with the courtyard. https://okuryazarim.com/category/sanattarihi/beylikler-donemi-sanati/ 


\section{Uncommon Layouts in the Plans of Ottoman Mosques in Greece (Rohodes and Crete Islands)}

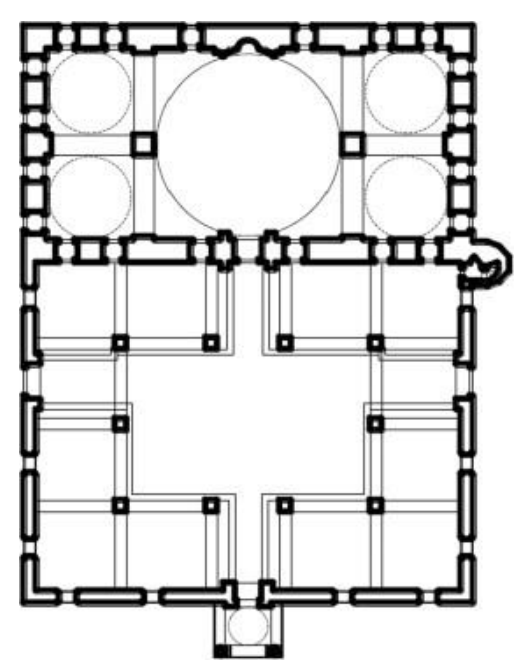

(Fig. 14) The courtyard layout of Guzelce Hassan Bey Mosque in Hayrabolu, Mustafa, 2019)

\subsection{The octagonal plan Mosque;}

The only surviving example in Ottoman architecture is Şadırvan Cami Rhodes within the boundaries of the fortress No. 15a-15d. It was constructed, according to the historical inscription, in (1305AH/1888AD) by Sinsn Bey under the supervision of Faraly Ali Zade Hadji Hafiz Huseyin Efendi and Osmancikhzade Hadji Mehmed Agha (Ibrahimgil, 2018).

The mosque was constructed on an octagonal ground plan, and the entire construction was built on the upper floor above the shops of the commercial center of the medieval town of Rhodes. The octagon structure was characterized by an octagonal plan form, whether a perfect regular eight-sided polygon with equal sides. The mosque was covered with a shallow dome on an octagonal base with spherical triangles as a transition zone from the internal side (Fig. 15- Pl. 5).

This octagonal plan was uncommon in mosques, so its examples are very rare. It could be seen in the octagonal double drum and dome of Orta Mosque in Veroia (896AH/ 1490AD) and Ali Paşa Mosque in Ohrid, Macedonia (981 AH/ 1573AD) (Zoren , 2008) (Pl.6). In contrast, it was more common in mausoleums and fountains, such as the turbe of Canbek Giray Khan (1046AH/ 1636AD), Shahin Giray (1050AH/ 1640AD) in Rhodes (Abdel Wahab, 2010), as well as the fountains of Rhodes and Kos mosques (Ibrahimgil,2018). 

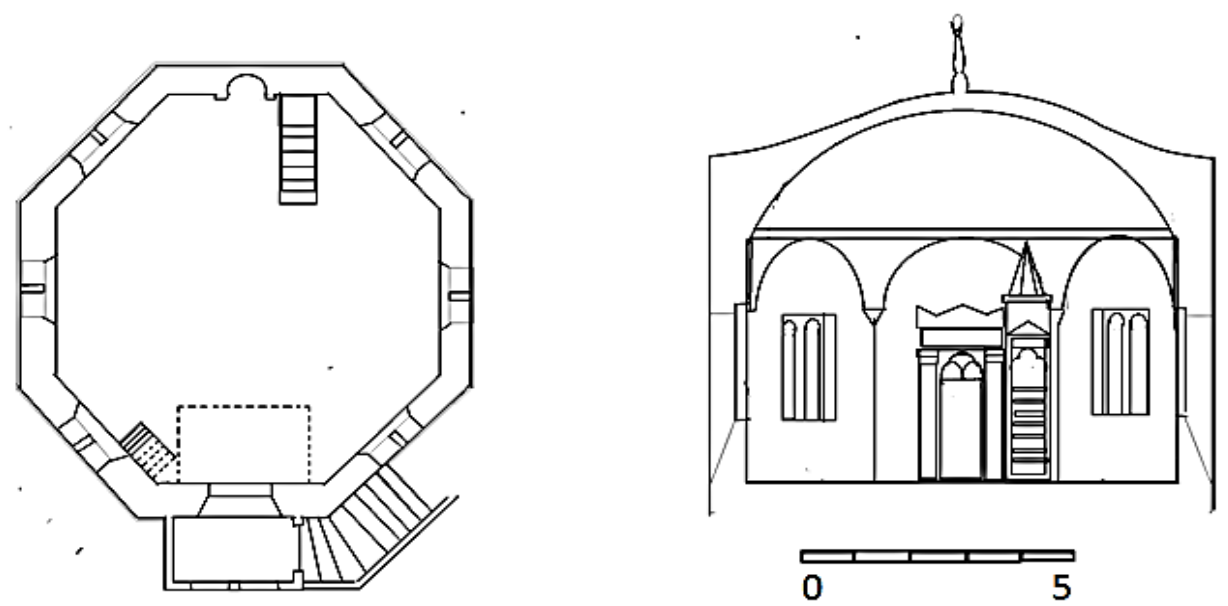

(Fig. 15): Section and octagonal plan of Şadırvan Cami, (Baldutcci,1932)a
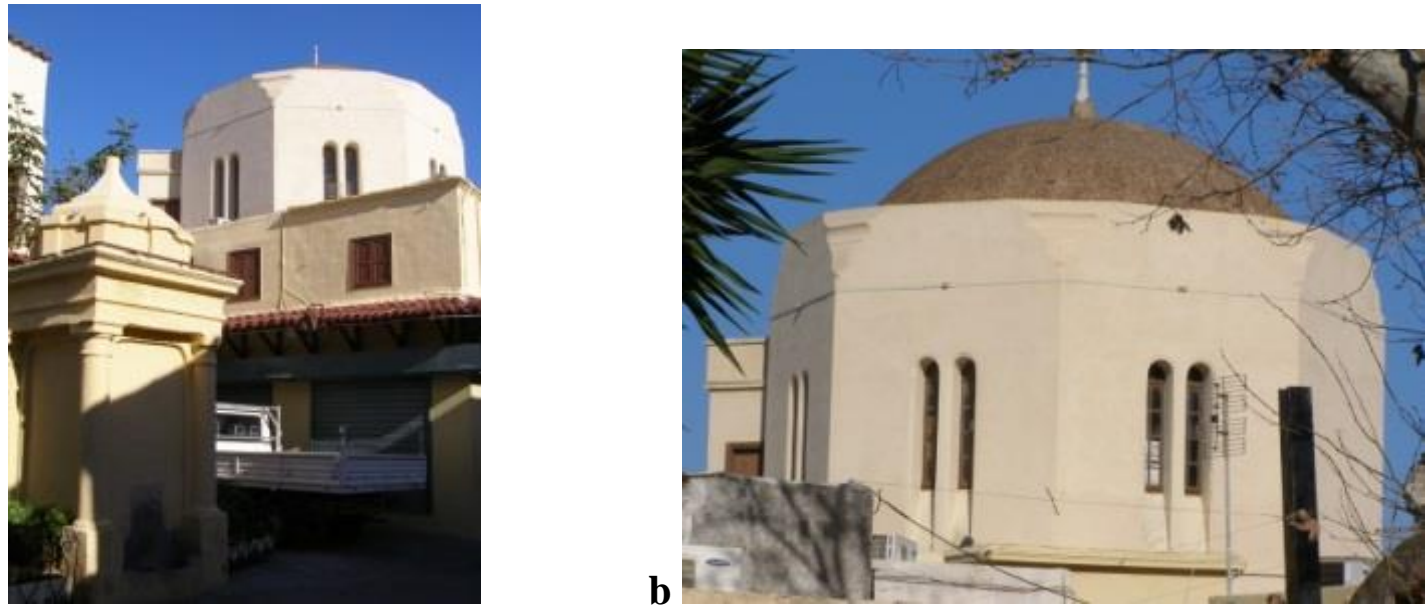

(Pl. 5) a- the hanging Şadırvan Cami and the fountain. b- details of Octagonal walls and the dome of Şadırvan Cami.

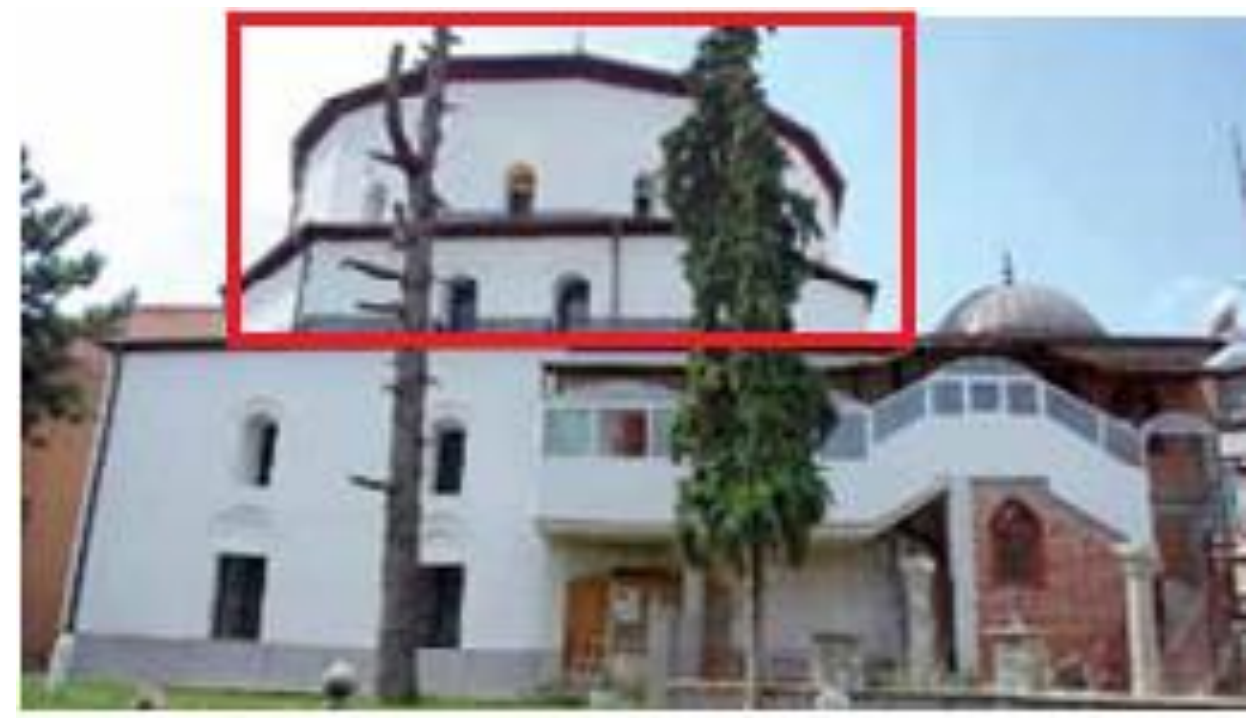


(P1. 6).The octagonal double drum and dome of Ali Paşa Mosque in Ohrid, Macedonia (1573).

https://www.123rf.com/photo_95204941_ali-Paşa -mosque-in-ohrid-macedonia.html

Şadırvan Camii is a very clear example of the Byzantine influence on Ottoman architecture. It could be detected in the transition system and resemblance between the churches' and mosques' plan "octagonal layout". There is a clear similarity between the octagonal plan of Şadırvan Camii and the plan of Byzantine churches, especially the form of the domes. The form, as well as the roofing type, reflects the influences of Byzantine churches, which were inverted to mosques in the old town of Rhodes, such as the domes of Dolabeli Mosque (St. Triada Church), Takdja Mosque (Agia Paraskevi Church), Chourmali Mosque (Agios Georgios

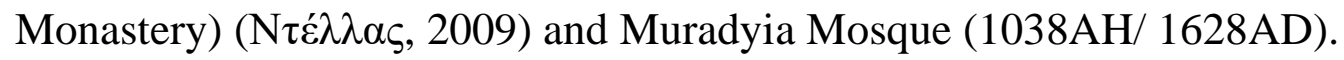
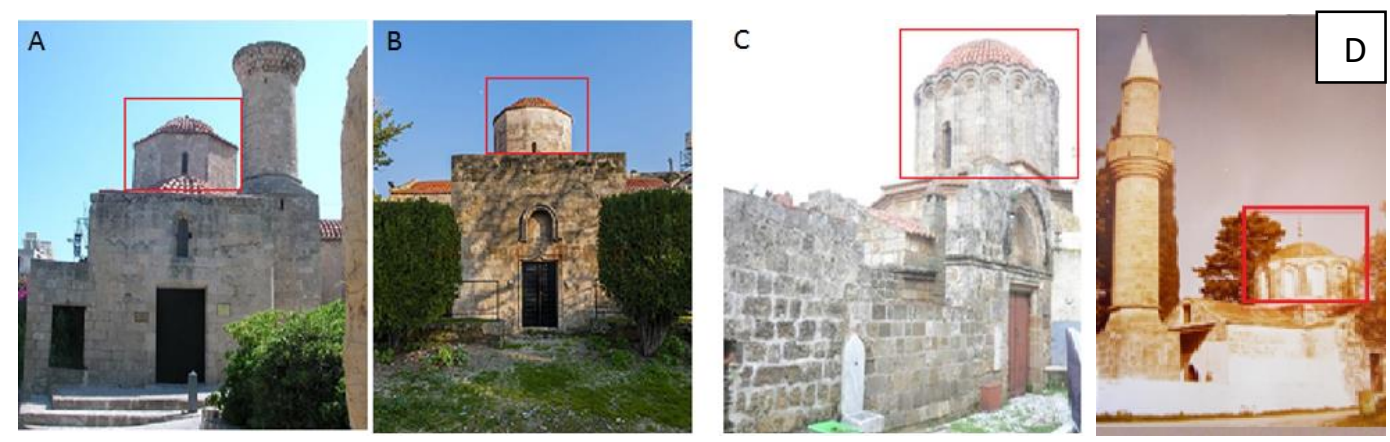

(P1.7) : the octagonal domes of Byzantine churches which converted to Mosques by Ottomans; A- St. Triada Church (Dolabeli Mosque) B-Agia Paraskevi Church which converted to Takdja Mosque. C- Agios Georgios Monastery (Chourmali Mosque). D- Muradyia Mosque.

At any rate, this layout was a common style of mosque plan not only in Ottoman architecture but also in Islamic architecture which preserved just one example of this octagonal design, i.e., the Mosque of the Dome of the Rock (72AH/ 691AD) in Palestine (Darwish,2016) - the oldest intact monument in Islamic architecture (Ameen, 2017). Therefore, this mosque form is an uncommon type of mosque not only in Ottoman architecture but also in Islamic architecture.

\subsection{Duplicate portico}

Küçük Hasan Mosque or (Yiali Camii) (1055-158AH/ 1645- 1648AD) is located inside the Venetian harbor at the prefecture of Chania in Crete Island. The mosque 
is not of the common type in Crete, which is a single-domed mosque with an open portico on the northwest side, such as Sultan Ibrahim and Kara Musa Paşa mosques in Rethymno.

This mosque has two open porticos: The first on the western wall and the second on the southern wall. These porticos were closed from outside in (1297AH/ 1880AD). The main room is square and measures $12 * 12 \mathrm{~m}$. It is roofed by a large hemispherical dome (Fig.16- Pl.7 ), supported externally on four arched buttresses. The dome rests directly on the perimeter walls by means of pointed arches and squinches, which are set into the walls (Fig.17- Pl.8).

The more recent (19th c.) marble mihrab, located in the southeast corner, is in the shape of a simple niche. Its upper part culminates in a Baroque pediment. The whole is enclosed within a framework of dressed stone with Koranic inscriptions (Bouroskari , 2008) (Pl. 8).

The most common portico in Ottoman mosques in Greece is three or five bays, such as in the Alaça Imaret (Ishak Paşa Mosque (889AH/ 1484AD) in Thessaloniki, Sultan Suleyman Mosque in Rhodes (930AH/ 1523AD) (Fig.4), and the Mosque of Zincirli in Serres $\left(16^{\text {th }}\right.$ century).

It is known that the plan of this type before and during the Ottoman era was preceded by only one front portico. Perhaps, this development in planning was an extension of the phenomenon of the presence of the three corridors surrounding the mosque from the outside, which did not appear in one of the Ottoman mosques before (920AH/ 1514AD) in the Lary Çelebi Mosque, Mustafa Bey Mosque in Serres (925AH/1519AD) (Ayverdi, 1966; Kiel, 1971; Bouroskari, 2008) (Fig.18), and Sinan Mosque in Cairo (979AH/ 1571AD) (Swelim, 1993) (Fig.19). In Küçük Hasan Mosque in Chania (1055-1058AH/ 1645-1648AD) due to the presence of a building adjacent to the Mosque, the architect could not use the third portico. 


\section{Uncommon Layouts in the Plans of Ottoman Mosques in Greece (Rohodes and Crete Islands)}

In fact, the attempt to identify the origin of this pattern in Ottoman architecture resulted in the lack of any similar examples. This two-arcade layout is the same as that of the dome mosque, but by adding an arcade in the northwest of the mosque. What are the factors that led to these additions, whether the additional side arcade or the unusual position of the mihrab as shown by the horizontal plan of the mosque?.

The recent excavations have shown that, on this spot, there was once a small oneroom church of St. Nicolao that was demolished and some of its architectural elements were reused in the structure of the mosque. Moreover, the design of the mosque was based on the old foundations of the church (Bouroskari, 2008).

Then, a new mosque was added. The evidence of that is that these additions to the mosque indicate that this building was modified in a later period of its construction to perform a religious function other than the one for which it was established. For example, the extension of the building axis is clearly heading from east to west according to its function as a church (St. Nikolaos). According to the recent excavations on the floor of the mosque, it became clear that the mosque had reused parts of the church structure and building materials in the new construction. It was modified by adding a niche in that corner in a way that does not match the design of the Ottoman mosques. The issue of ensuring that the interior rows of the worshipers are completely parallel to the qibla wall is observed in all mosques dating back to this era (Digital Crete, 2012)

In this case, it appears the extent of the effect of reusing old foundations and the site conditions in forming spaces in the mosque. Evliya Çelebi argued that all Reythimno mosques were built on the ruins of old churches (Evliya, 2003).

The architectural design of the ancient foundations of St. Nikolaos was an obstacle in front of the architect when he tried to direct the internal space and the apse of the mosque's mihrab towards the qibla (southeast direction), which led to the mihrab block in the best corner of the prayer house and not in the middle of the southeast wall of the mosque as is the case in all Ottoman mosques, which could not be found in Küçük Hasan Paşa Mosque. 


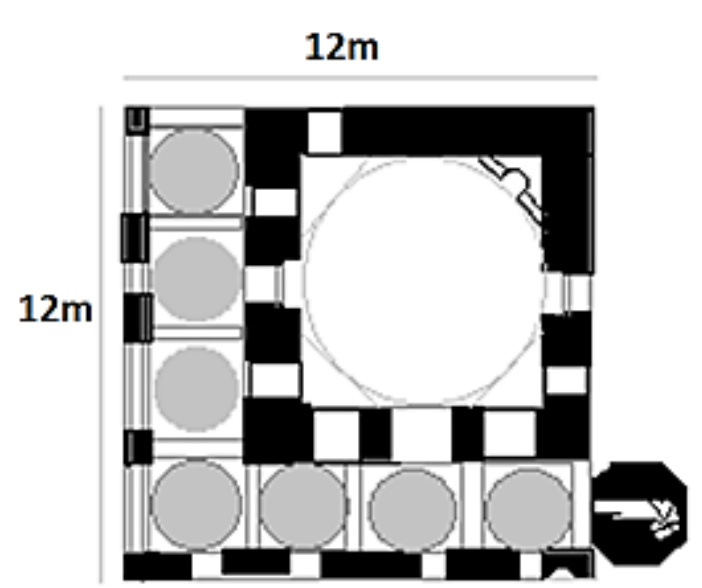

(Fig.16) Plan of Küçük Hasan Mosque. after (Bourskari, 2008).

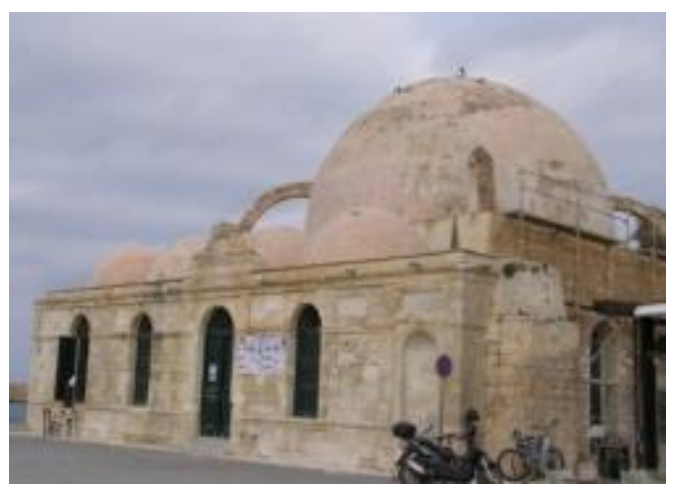

(Pl. 7) the western portico of Küçük Hasan Mosque

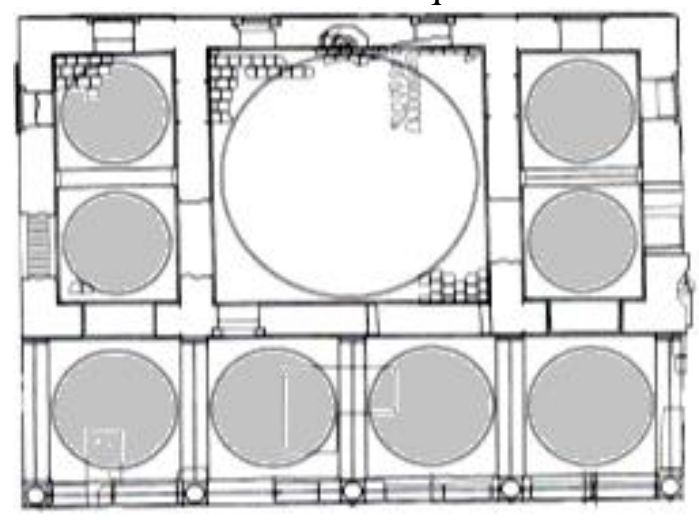

(Fig.18 ): Mustafa Bey Mosque in Serres 1519. After Bouroskari, 2008).

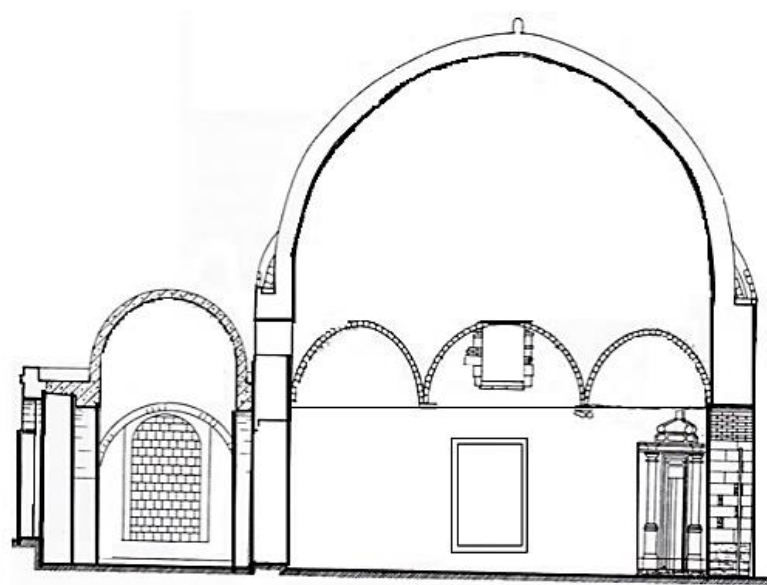

(Fig.17) Section of Küçűk Hasan Mosque. (Bourskari, 2008).

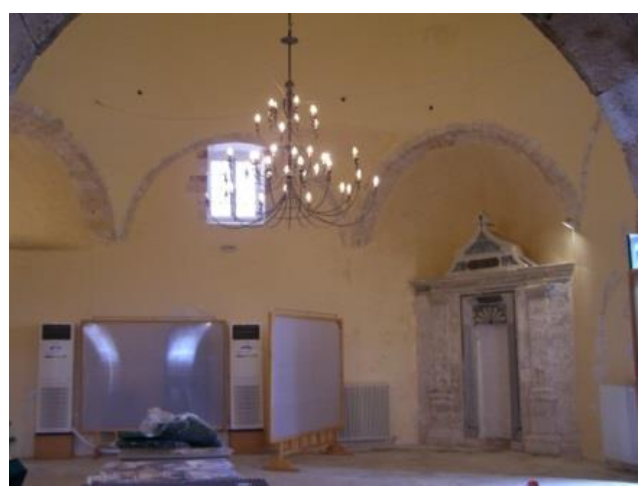

(Pl. 8) the internal tranzation zone of Küçük Hasan Mosque.

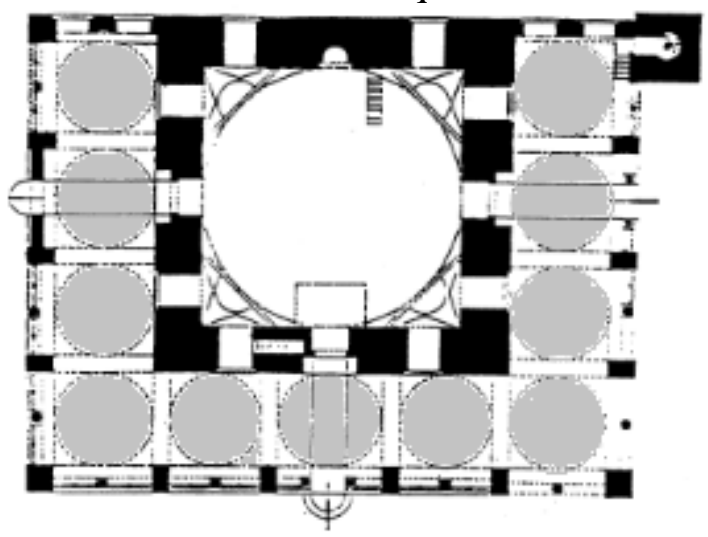

(Fig.19) : Plan of Sinan Mosque in Cairo. (after Swelim, 1993). 


\subsection{The tribble-domed spaces}

This category is characterized by a rectangular layout with arrangements of pointed arches and spherical triangle pendentives as a transition zone that supports three domes, creating three domed units along an e-west axis.

The PAŞA ÇAMII is representative of the characteristics of this category (Figs 20, 21- Pl. 9). It was constructed in the old town of Rethymno by Gazi Deli HÜSEYIN PAŞA in HIS MAHALLESI (QUARTER), the commander-in-chief of the Ottoman army in Crete (1056-1067AH/ 1646-1656AD) and the conqueror of Rethymno. Originally, the complex had a mosque, an imaret, a school, a turbe, and a kütüphane (library), but the Paşa did not construct new buildings. He used the old buildings and foundations of the Venetian period and found new functions. The church of the Holy Virgin and the chapel of Corpus Christi were converted to a mosque and a library (Bourskari, 2008). These constructions were adapted to the pre-existing Venetian church to turn it into a viable mosque on the roof (Pl.10). The southern and the eastern walls were rebuilt.

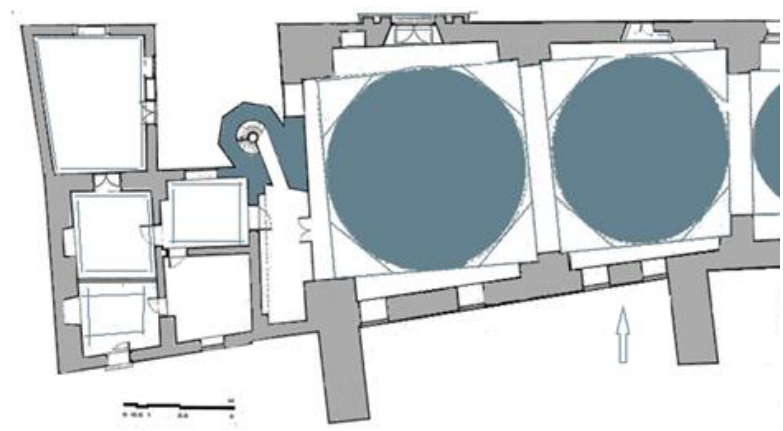

(Fig.20) Plan of Gazi Deli Huseyin Paşa Mosque document the Venetian foundations and Ottoman elements. (after Bourskari, 2008)

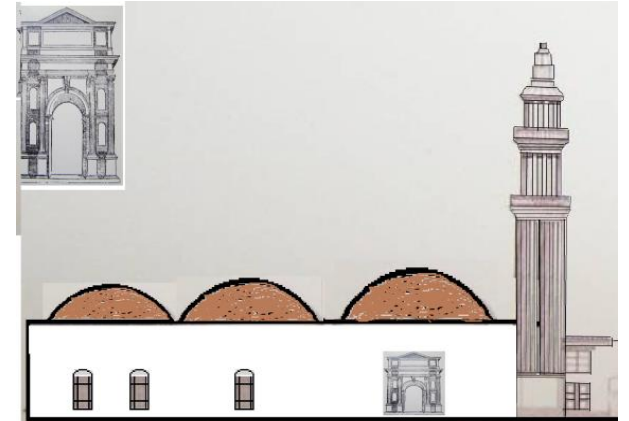

(Fig.21) Section of Gazi Deli HÜSEYIN PAŞA in HÜSEYIN PAŞA

Mosque . (after Bourskari, 2008) 


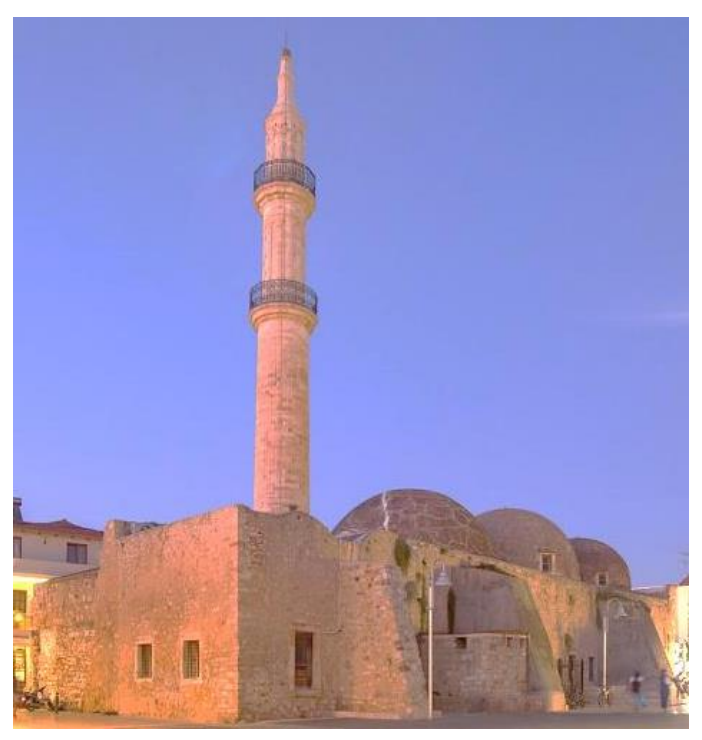

(Pl. 9) the South façade of Gazi Deli Huseyin Paşa Mosque.

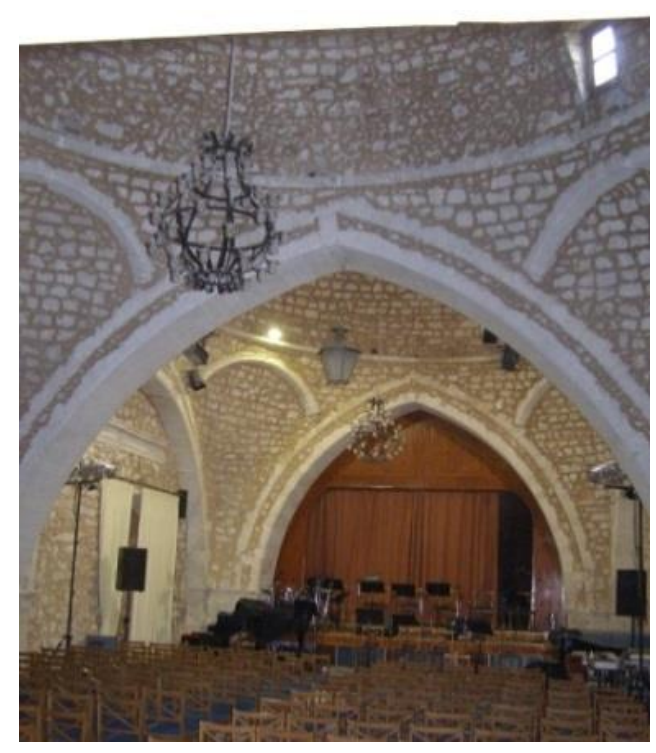

(Pl. 10) the internal space of Gazi Deli Huseyin Paşa Mosque.

Although the architectural design of this mosque is a clear reflection of the effect of reusing the old foundations of the Church of the Holy Virgin whose existing walls and foundations and perhaps entire architectural units enforced the architect to arrange the interior spaces of the mosque in this layout. This design was familiar to the Ottoman architect, especially in commercial and public constructions in terms of arranging the internal spaces on a continuous transverse axis and covering them with successive domes next to each other, including, for example, the Evrenos Bey Khan (777-782AH/ 1375-1380AD) (Hamza, 2002) (Fig. 22).

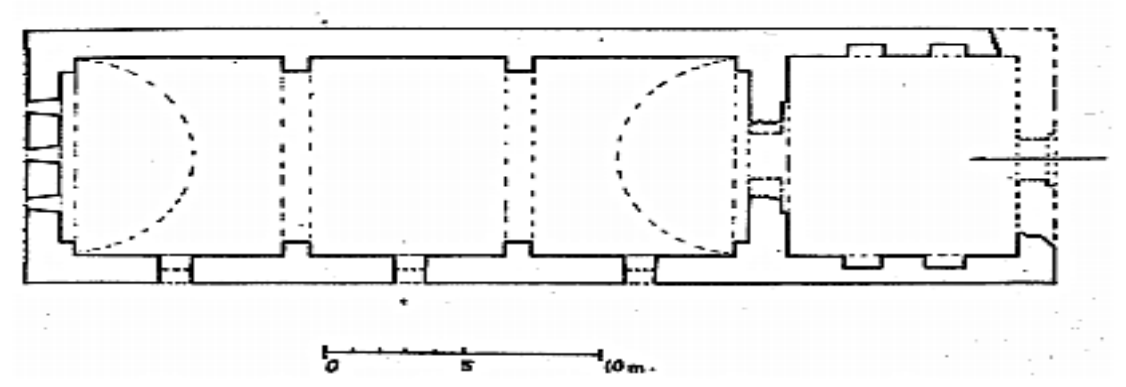

(Fig.22): The plan of Ghazi Evrenos Bey Khan (Ilica-Loutra) (Kiel, 1990)

This type of Gazi Deli HÜSEYIN PAŞA MOSQUE AND EVRENOS BEY KHAN WERE RELATED TO SOME WORKS OF EARLY OTTOMAN ARCHITECTURE IN ANATOLIA. THE IDEA, IN GENERAL, IS THE SAME AS THAT OF DÖĞER KHAN IN AFYONKARAHISAR (Kiel, 1990). THE 
Uncommon Layouts in the Plans of Ottoman Mosques in Greece (Rohodes and Crete Islands)

PRINCIPAL DIFFERENCE BETWEEN THE PLANS of Evrenos Bey Khan and both of Gazi Deli HÜSEYIN PAŞA MOSQUE AND DÖĞER KHAN is the main entrance, which was situated in one of the long side walls, whereas in Evrenos Bey it was placed in one of the short sidewalls (Kiel, 1990).

The tribble-domed spaces of Gazi Deli HÜSEYIN PAŞA MOSQUE AND EVRENOS BEY KHAN WERE MOTIVATED BY THE VAST COVERED HALLS OF THE SELJUK KHANS IN ANATOLIA IN THE $13^{\mathrm{TH}}$ CENTURY, SUCH AS ESHAB-I KEHF KHAN NEAR ELBISTAN, THE KIRKGÖZ KHAN NEAR ANTALYA, AND MAMA HATUN KHAN IN TERCAN (Kiel, 1990).

\subsection{The double-dome layout:}

The double-dome layout design is a combination of the single dome without the porch, which was often used in Ottoman mosques. The prayer hall or two covered spaces are rectangular and designed horizontally on the qibla wall.

An example of this category is the Mosque of Valide Sultan (1050-1058AH/ 16401648AD) (Fig.23- Pl.11). It was constructed by Valide Sultan Turokhan Khadija who was one of Sultan Ibrahim's Harime (1050-1058AH/ 1640-1648AD) till the born of Sultan Mehmet VI (Süreyya, 1996). The building consists of two domed spaces with a rectangular floor plan. The characteristic pointed squinches support the domes. Evliya Çelebi mentioned that this mosque was at the time of construction inside the Kapuso Tekke Gate (Evliya, 2003). The mosque's presence inside this Tekke may explain the size and layout of the mosque, as the design came according to the available space inside the walls of the old Tekke and on previous foundations in the location (Bourskari, 2008).

When searching the origin of this layout, we find that Ottoman architecture was accustomed to this horizontal plan so its example is very rare. This layout resembles, in its plan, the horizontal plan of the library of Ahmed Hafiz Agha in Rhodes (1187AH/ 1793AD) (Celakkol, 1992) (Fig.23, Pl.12), which, according to 
some studies, was used for prayer though we do not find any archaeological evidence (Celakkol, 1992).
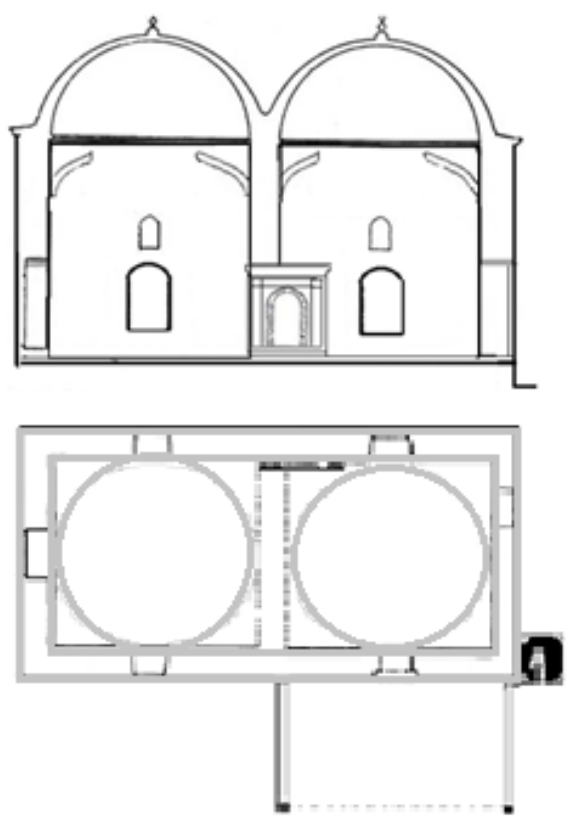

(Fig. 23) Section and plan of Valide Sultan Turokhan Khadija Mosque.

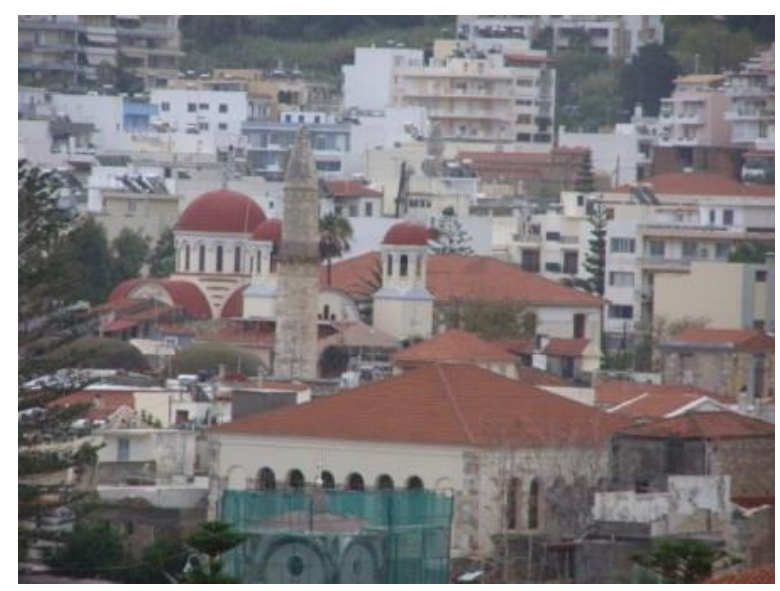

(Pl. 11) the double dome Mosque of Valide Sultan Turokhan Khadija.
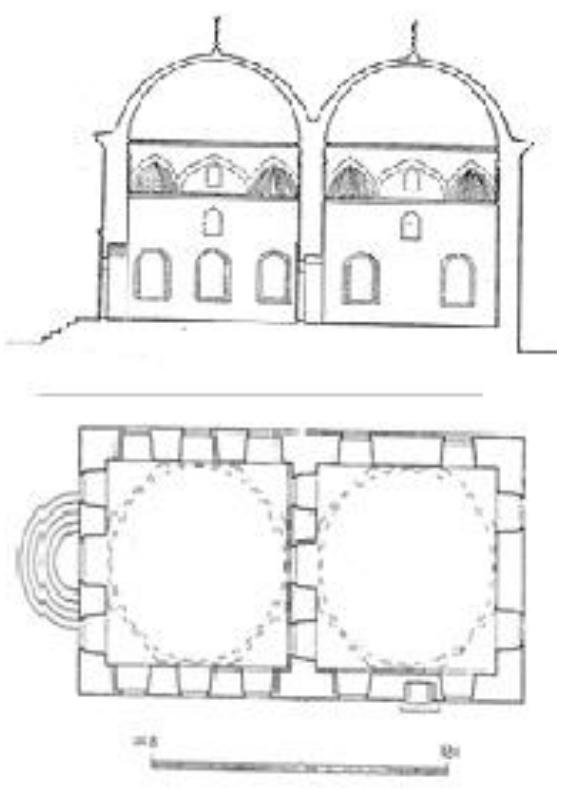

(Fig. 24) Section and plan of Ahmet Hafiz Aga library, Rhodes . (Baldutcci, 1932)

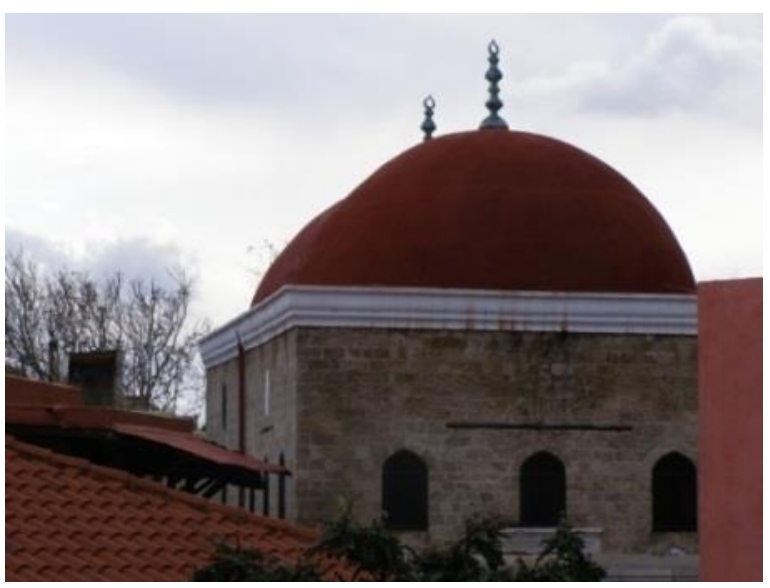

(Pl.12) the double domes of Ahmet Hafiz Aga library, Rhodes.

\subsection{Pogada roof}

The layout of Ali Hilmi Paşa Mosque is an example of the common mosquedome type (Fig.25, Pl. 13), but the pogada roof is an uncommon element. The mosque is a square building, $10 \mathrm{~m}^{*} 10 \mathrm{~m}$., without minaret, inside, the simple and undecorated prayer area -along the southeast wall- preserves its ritual elements; the 


\section{Uncommon Layouts in the Plans of Ottoman Mosques in Greece (Rohodes and Crete Islands)}

marble prayer niche, the wooden minbar, and Koranic Kürsü. Along the northwest wall, the mosque preserves the wooden women's compartment (gallery). The prayer hall is covered from inside by an octagonal dome that rises to a point and rests on four pendentives to affect the transition from the square plan of the prayer space to the octagon. The roof takes the form of an octagon supported by wooden corbels, which all meet at the central peak that is shaped like a pagoda(Kaka, 2008).

The mosque was constructed in Ramadan (1327AH/ 1909AD) by the Egyptian Ali Hilmi Paşa who was in Rhodes in the first quarter of the $20^{\text {th }}$ century. It was founded to serve the Muslims outside the fortress walls (Ibrahimgil , 2018) (Pl. 14).

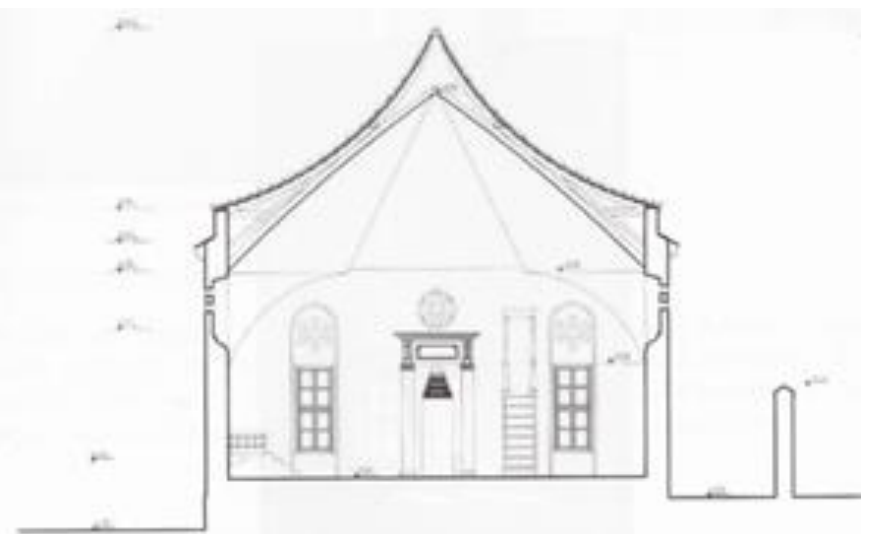

(Fig.25) Pogada roof of Ali Hilmi Paşa, Rhodes 1909AD.

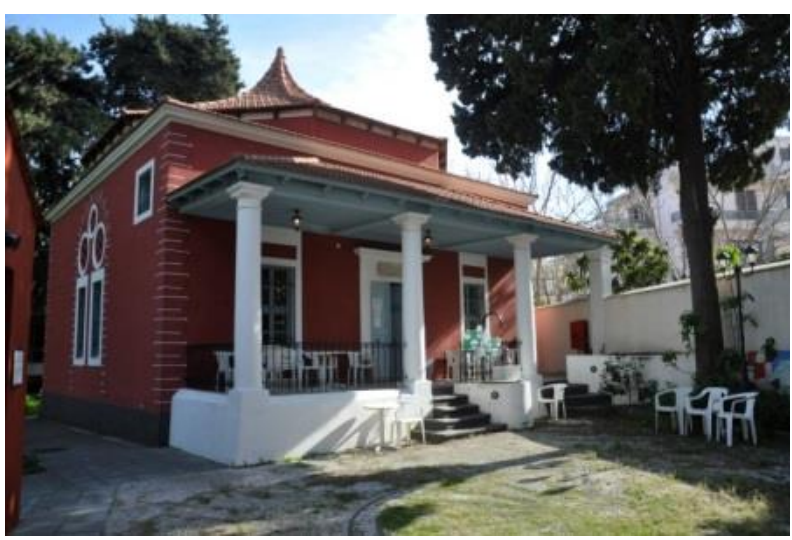

(Pl. 13) the mosque of a Ali Hilmi Paşa, Rhodes.

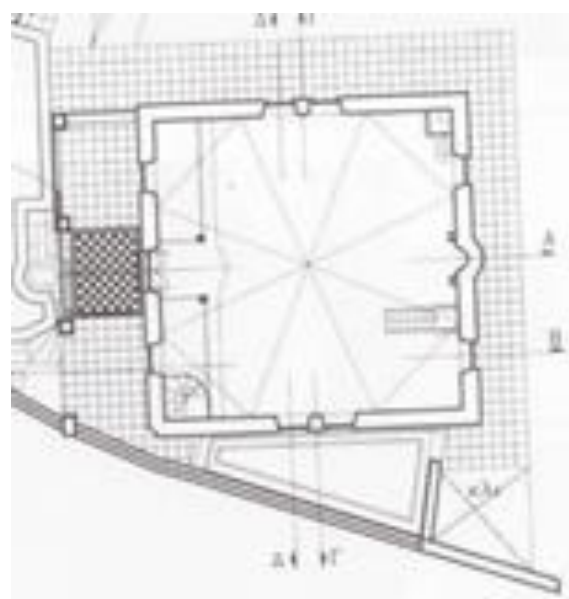

(Fig.26) Chinese roofs which wellknown pagoda.

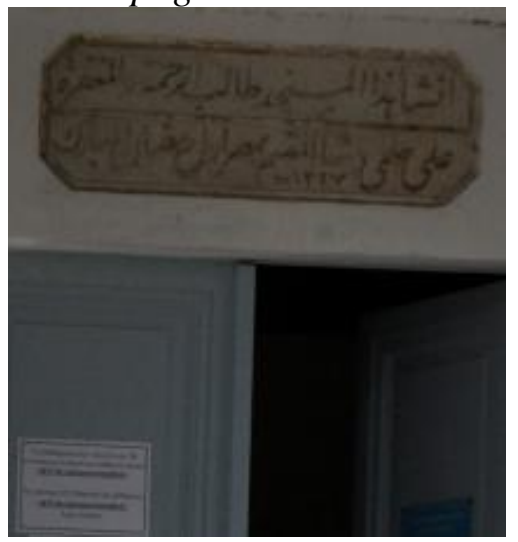

(Pl.14) the historical inscription of Ali Hilmi Paşa.

We can recognize that the flat roofs were uncommon in Ottoman mosque architecture, while domed and gabled roofs were almost omnipresent in Ottoman 
architecture. Gabled roofs were built on roof cross-beams and sometimes were rested directly on vertical structural beams. The Ottoman mosques represented two types of gabled roofs:

The first: Straight inclined with a single incline. This type was the most economical type of roofing and the most common in European Ottoman mosques.

The second: Sweeping- roof with a sweeping curvature that rises at the octagonal drum. It consists of a hip roof that slopes down on all eight sides and integrates a gable on two opposing sides. This roof construction preserved in Ali Hilmi Paşa Mosque looks like Hindu, Buddhist, or Chinese architectural elements. Chinese roofs known as pagoda are based on an octagonal drum and covered from outside with eight spherical triangles pendentives, while from inside the section of the roof is a triangle (Fig. 26). The architect used the traditional Ottoman technique in which wooden boards were fixed and then reed strips were plaited together uniformly. The roof would be covered with such plaited reed on top of the wooden trunks and boards. All should be covered with mortar made of red earth Rhodes and finally covered with a layer of tiles of baked bricks. Such roofs were composed of wooden trunks and logs, plaited reed strips, red mortar, and tiles of red burnt bricks (Kala , 2009).

This type of roof construction was unusual in covering a mosque and was certainly unique in Ottoman architecture. It is usually reserved for Chinese mosques and palaces (Li , 1979).

It could be said that the typology of the mosque depending on the plan is very common as the remaining examples of Ottoman mosques (the single prayer space or the dome mosque), with a hemispherical dome, were commonly based on an octagon drum. The roof of the single prayer space was a unique and uncommon type. 
This type of roofs was different from the gable roofs, which was used in many Ottoman mosques, such as Mehmet Çelebi (823AH/ 1420AD)

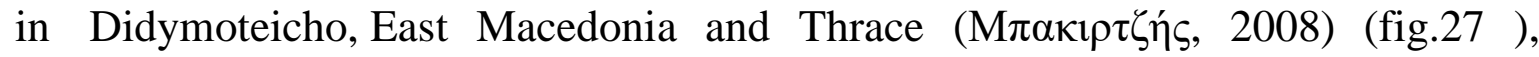
Mehmet Aga Mosque (1236-1292AH/ 1820-1875AD) in Rhodes, the Mosques of Hasan Paşa in Kos Island and Yehia Paşa in Ascoop (909AH/ 1503AD) and Haji Hussein Bin Abdallah Mosque (Carsi Camii or the market Mosque) in Pirlepe, Yugoslavian Macedonia (881AH/ 1476AD) (Ayverdi,1979; Kiel, 1990), Yeni Camii in Nicosia and the Grand Mosque in Larnaka in Cyprus (Oglu, 1951). However, the most important surviving example of the mosques covered with gable roofs is the Murad II Mosque in Scoop (840AH/ 1436A.D) (Ayverdi, 1957).

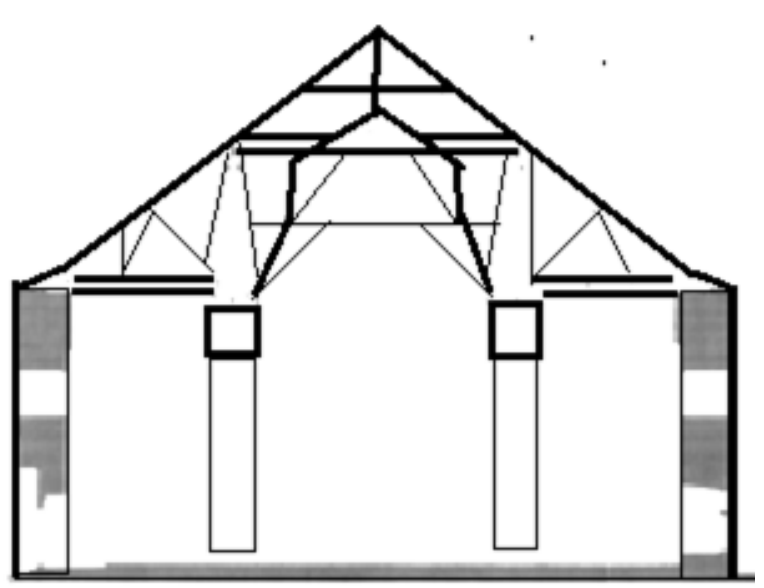

(Fig. 27) Section of the gable roof of Mehmet Çelebi mosque, Didymoteicho (1420), (after Bourskar,2008)..

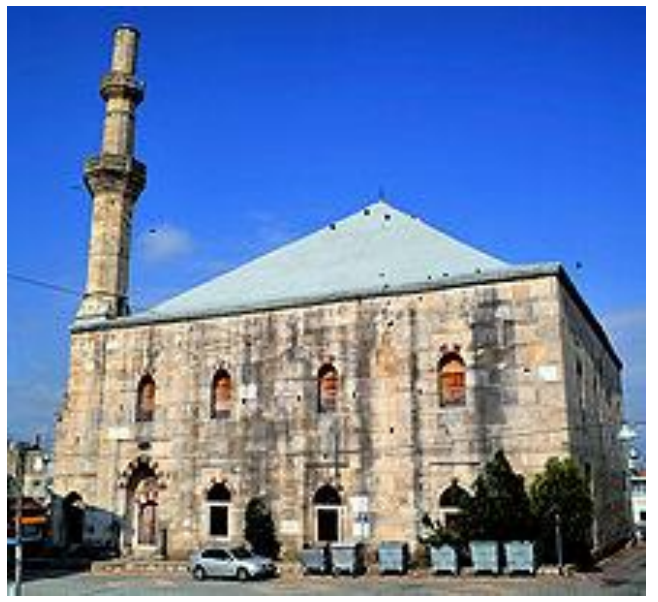

(Pl.15). the gable roof of Mehmet Çelebi mosque, Didymoteicho (1420), (Bourskar,2008).

\section{Conclusion}

While studying and analyzing the unique typology of Ottoman mosques in Balkan and Greece, all researchers confirm the conclusions of architecture historians about the very special characteristics and features of mosques in this area. In this context, there were many influences of pre-existing sites in Greece. The existing buildings in Byzantine cities were used through conversions with few transformations. In the early Ottoman mosques, it could be seen in the reuse of the foundations of older Byzantine and Venetian buildings and the use of spolia. This was done in Küçúk 
Hasan Mosque, Chania, and Crete where the old foundations imposed a unique architectural design on the site represented in the addition of two external aisles open to the outside only. It was usual in Ottoman architecture to add one external arcade on the northwest side - known as the dome mosque, such as the Sultan Ibrahim Mosque and the Qara Musa Paşa Priemno Mosque, or adding three external aisles, as is the case in the Sinan Paşa Mosque in Cairo. In Gazi Deli Huseyin Paşa Mosque in Rethymno, the ancient foundations of the site affected the architectural design of the internal spaces designated for prayer. Therefore, the mosque had an axial design, consisting of three successive domes of unequal dimensions as a direct result of the effect of restoring the foundations of the old church. Moreover, there was a distribution of architectural elements in unusual locations in Ottoman mosques with their different styles, which resulted in an uncommon architectural design that came as a direct result of the conditions of the old site and the reuse of the elements in the architecture of Byzantine and Venetian style.

There is a similarity between the building techniques, decoration, and architectural elements. For example, the octagonal plan covered with domes supported by windowed drums and the plan of prayer space are similar to the octagonal Byzantine churches in the island category, such as the design of the Sdrivan Mosque in Rhodes.

In general, the use of Byzantine spolia in the mosques of Greece, with the most characteristic being the byzantine capitals, illustrates the permanence of Byzantine practices in the early Ottoman mosques.

\section{9- Results}

The common layout of Ottoman mosques in Greece is characterized by simplicity based on the tradition of each area. They are classified into general two main categories:

\section{-The single-unit mosque}

\section{-The single-unit mosques with lateral spaces}

During the process of the present survey in Greek lands, six buildings designed with an uncommon layout were found in the cities of Thessaloniki, Rhodes, and Crete islands.

- Duplication dome layout or the multi-domed mosque, such as Vali Paşa Mosque in Rethymno, Crete (1062AH/ 1651AD). 
- Courtyard layout design, such as Hamza Bey Mosque (Alkazar) in Thessaloniki (872-873AH/ 1467-1468AD).

- The octagonal type, such as Şadırvan Cami Rhodes. This mosque represented the Byzantine influence on Ottoman architecture. It could be detected in the transition system and resemblance between the church and mosque plan "octagonal layout".

- Duplicate portico, such as the Mosque of Küçük Hasan Mosque or (Yiali Camii) (1055-1058AH/ 1645- 1648AD)

- The tribble-domed spaces, such as Gazi Deli HÜSEYIN PAŞA, Rethymno, Crete (1056-1067AH/ 1646-1656AD)

- The double domes layout, such as the Mosque of Valide Sultan, Rethymno, Crete (1050-1058AH/ 1640-1648AD)

We can recognize that the flat roofs were uncommon in the Ottoman mosque architecture, while domed and gabled roofs were almost omnipresent in Ottoman architecture; gabled roofs were built on roof cross-beams and sometimes were rested directly on vertical structural beams. The Ottoman mosques represented two types of gabled roofs:

The first: Straight inclined roof

The second: Sweeping roof

This type of roof construction was an unusual type for covering a mosque. It was certainly unique in Ottoman architecture.

There were many influences of pre-existing sites and spolia in Greece, and the existing buildings in Byzantine cities were used by making few transformations. This was more common in early Ottoman mosques. 


\section{References}

1. Abdel Wahab. M (2020), The typology of the Ottoman mausoleums in Rhodes in the light of the remaining types in cemetery of Murad Re'is Egyptian Journal of Archaeological and Restoration Studies (EJARS), Vol.10 (1), June 2020, pp. 87101.

2. Abdel Wahab. M (2010), the Ottoman Mosques in the Old town of Rhodes Island, Ph.D, Archaeology and History of Art Dept, Faculty of Philosophy, National and Kapodistrian University of Athens.

3. Ameen A (2017), Islamic Architecture in Greece: Mosques. Foreword: Dr. Mostafa El Feki, Center for Islamic Civilization studies, Bibliotheca Alexandrina, Alexandria.

4. Ameen. A (2019), Patrons of Ottoman Mosques In Greece reconsidered in light of the Ierapetra Mosque of Crete, Journal of Islamic Architecture, 5 (3), June, pp. 137144.

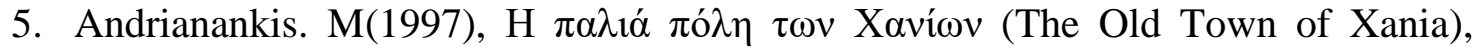
Athens.

6. Aslanapa. O (1987), The Turkish Arts and Architecture, Istanbul.

7. Kuran. K (1968) The Mosque in Early Ottoman Architecture, University of Chicago-London.

8. Ayverdi. E (1972), İstanbul Mimari Çağının Menşei - Osmanlı Mimarisinin İlk Devri 630-805(1230-1402), İstanbul Fetih Cemiyeti, İstanbul Enstitüsü, No. 57 , İstanbul, 1972. pp.153-154.

9. Ayverdi. E (1974), Osmanli Mi'marisinin ilk Devri (Early Ottoman Architecture, 4 vols. (istanbul Fetih Cem'iyeti, istanbul Enstitisii, Istanbul), 1966, 1972, 1973, 1974. 3 and 4 form Istanbul Enstitiisu No.69.

10. Ayverdi. E (1989), Osmanlı Mi'mârî çağının Menşe'i Osmanlı Mi'mârîsinin İlk Devri Ertuğrul, Osman, Orhan Gaaziler Hüdavendigâr ve Yıldırım Bâyezid 630 805 (1260-1402) [The Origins of Ottoman Architecture, The First Period of Ottoman Architecture, Periods of Ertuğrul, Osman and Orhan Gazis, Hüdavendigar and Y1ldırım Bayezid 630-805 (1260-1402), 2nd edition, Istanbul..

11. Balducci. H (1932), Architettura turca in Rodi (The Turkish architecture in Rhodes), Milano.

12. The Ottoman Architecture in Greece.

13. Bouroskari. E (2008), Ottoman Architecture in Greece. Athens: Hellenic Ministry of Culture, Directorate of Byzantine; Post-Byzantine Antiquities.

14. Celakkol. Z (1992), Rodes Taki Turk Eserleri ve Tarihce (The Turkish Monuments in Rhodes and their History), Ankara.

15. Cincin. S (2016), Ottoman monumental Buildings in Thessaloniki Architectural Heritage, Journal Of Emerging Economies And Policy (JOEEP) Vol.1, December 2016, PP. 73-84.

16. Darwish. M (2016), The Architectural octagonal planning (Dome of the Rock and European churches, Journal of International Acadimic Research for Multidisciplinary, Vol. 4, Issue 8, September, pp. 1-23. 


\section{Uncommon Layouts in the Plans of Ottoman Mosques in Greece (Rohodes and Crete Islands)}

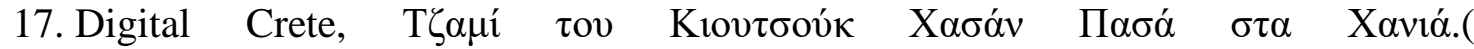
https://www.crete.gr/el/pages/tzami-kioutsouk-chania.php) .

18. Eleni. E (2004), the creation of historical cultural heritage during the Ottoman period, Balkanlarda Osmanlı Vakıfları ve Eserleri Uluslararası Sempozyumu, Ankara, 2004, pp. 197-208.

19. Evliya. Ç (2003), Seyahatnamesi Topkapı Sarayı Kütüphanesi Bağdat 308

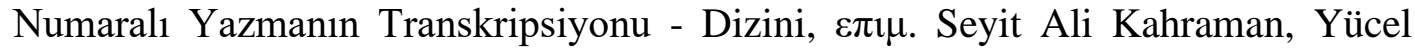

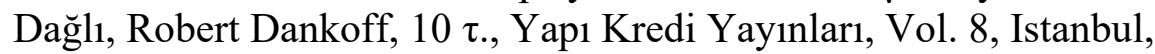

20. Mustafa. F. \& Hassan. A (2019), A typological Study of the Historical Mosques in Erbil City, Sulaimani Journal for Engineering Sciences / Volume 6 - Number 3, pp. 11-28.

21. Gulgonen. A \& Laisney. F (1982), Contextual approaches to typology at the Ecole des Beaux- Arts. Journal of Architectural Education, Typology in design education, Associatition of Collegiate schools of architecture Inc, Vol. 35, No. 2, pp. 26-28.

22. Hamza. M (2002), the Ottoman architecture in Europe, Kuveyt university, Kuveyt.

23. https://historicalcrete.ims.forth.gr/Toponyms/listing/gazi-chouse\%CE\%90n-pasa6/2/2021-08:14 pm

24. https://okuryazarim.com/selcuk-isa-bey-cami/

25. https://www.didymoteicho.gr/el/didymoteicho/mouseia/temenos-vayazid.html

26. İbrahimgil. M. \& İbrahimgil. A (2018), Rodos'ta Osmanlı mirasi, mimari eserler kitabeler- mezartaşları (Ottoman heritage in Rhodes: ArchitectureinscriptionsTombstones), Sota, Haarlem.

27. Freely. J (2011), A history of Ottoman Architecture, Wit press, Southampton, Boston, 2011.

28. Kaka. E (2008), Ali Hilmi Pasha mosque, in Ottoman architecture in Greece, , Hellenic Ministry of Cultcure, Athens.

29. Kala. E(2009), Restoration of Ali Hilmi Pasha Mosque and Park,1 Pindou St.

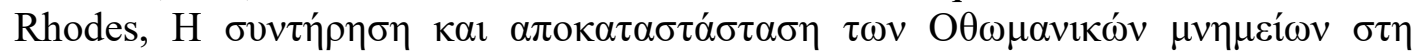

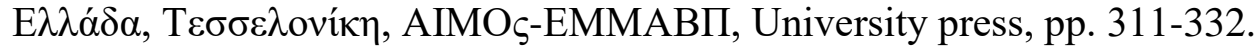

30. Kiel. M, Deriziotis. L (1990), "The old bedesten of Larissa(Yenisehir) in restoration," in: Seventh International Congress of Turkish Art, Warsaw, pp. 141145.

31. Kiel. M (2002), "The quatrefoil plan in Ottoman architecture reconsidered in light of the 'Fethiye Mosque of Athens," in: Muqarnas, XIX, pp. 109-122.

32. Kiel, M., Ottoman architecture in Albania, 1385-1912. Istanbul: IRCICA, 1990.

33. Kiel. M (1976), "Some little-known monuments of Ottoman Turkish architecture in the Macedonian province: Štip, Kumanovo, Prilep, Strumitsa" GüneyDoğu Avrupa Araştırmaları Dergisi, IV/V, pp. 153-96.

34. Kiel. M (1983), “The Oldest Monuments of Ottoman-Turkish Architecture in the Balkans: The Imaret and the Mosque of Ghazi, Evrenos Bey in Giimiilcine (Komotini) and the Evrenos Bey Khan in the Village of Ilica Loutra in Greek Thrace (1370-1390)," in: Sanat Tarihi Yillı̆̆l-Kunsthistorische Forschungen 12, Istanbul, PP.117-144.

35. Kiel. M (1971), "Observations on the History of Northern Greece during the Turkish Rule: Historical and Architectural Description of the Turkish 
Monuments of Komotini and Serres, their Place in the Development of Ottoman Turkish Architecture and their Present Condition”, Balkan Studies 12/2, 429-444.

36. Kiel. M (1981), "Some little known monuments of early and classical Ottoman Architecture in Greek Thrace", BS, .22 (1981), 80-95.

37. Konuk. N(2008), Ottoman architecture in Lesvos, Rhodes, Chios, and Kos Islands, Istanbul 2008.

38. Zoren. P (2008), Macedonian Cultural Heritage, Ottoman monuments, - Regional Bureau for Science and Culture in Europe (UNESCO-BRESCE) and Cooperazione Italiana, Skopje 2008, p.44.

39. Kuran. K (1968), The Mosque in Early Ottoman Architecture (Chicago, London: University of Chicago Press, PP.71-136.

40. Kuyulu. I (1999), “İsa Bey Camii", Erken Osmanl Sanatl, Beyliklerin Mirast, [Early Ottoman Art: The Legacy of the Emirates], Madrid, pp.60-61.

41. Ogan. A (1956), "Aydın Oğullarından İsa Bey Camii [The Mosque of İsa Bey of Aydınoğlus]", Vakıflar Dergisi, [http://islamicart.museumwnf.org/database_item.php?id=monument;ISL;tr;Mon01; $11 ;$ en\&cp]

42. Li Y (1979), "Chinese Geomancy and Ancestor Worship: A Further Discussion". Ancestors, De Gruyter Mouton, Germany, pp. 329-338.

43. Loukma. M, Stefanidou.M (2017), The morphology and typology of the Ottoman mosques of northern Greece, Int. J. of Herit. Archit., Vol. 1, No. 1, , PP.78-88.

44. Nusret. C (2000), Turkish monuments in Greece, Turk Tarih Kurumu Basimevi, Ankara.

45. Oguz. Z (2006), Multi-functional Buildings of the T-type in Ottoman context: a network of identity and territorialization, M.A, School of Social Sciences of Middle East Technical University, Ankara.

46. Panagiotis. K (2012), Beyond Typology: Zaviye and T-Shape Buildings in the Balkans. Some Thoughts on their Urban Context and their Possible Use, PP. 243265.

47. Cincin.S (2016), Ottoman monumental Buildings in Thessaloniki Architectural Heritage, Journal Of emerging economies and policy (JOEEP) Vol.1, December, pp. 73-84.

48. Slie. P(1933), The Imperial Harem: Women and Sovereignty in the Ottoman Empire. Oxford University Pres, PP. 106- 107.

49. Süreyya. M (1996), Sicill-i osmani /osmanlı ünlüleri, Translation. Seyit Ali Kahraman, Editor. Nuri Akbayar, Tarih Vakfi, Istanbul.

50. Swelim. T(1993), "An Interpretation of the Mosque of Sinan Pasha in Cairo", Muqarnas, vol. 10, , PP. 98-107.

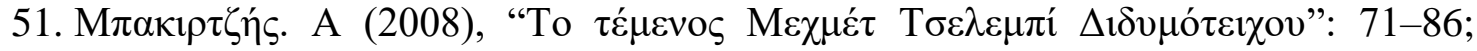
OAG.PP. 330-332.

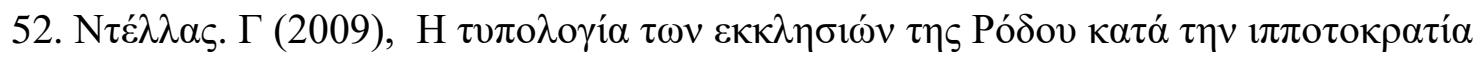

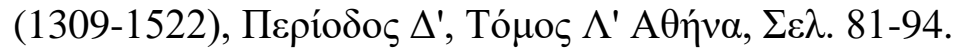

